\title{
Evaluating the Sustainable Operating Performance of Electronics Industry Groups: Taiwanese Firms in Mainland China
}

\author{
Shu-Chuan Chen ${ }^{1}$, Da-Sheng Lee ${ }^{2}$ and Chien-Yi Huang ${ }^{1, *}$ \\ 1 Department of Industrial Engineering and Management, National Taipei University of Technology, \\ Taipei 10608, Taiwan; t106379001@ntut.edu.tw \\ 2 Department of Energy and Refrigerating Air-Conditioning Engineering, National Taipei University of \\ Technology, Taipei 10608, Taiwan; f11167@ntut.edu.tw \\ * Correspondence: jayhuang@mail.ntut.edu.tw
}

check for updates

Citation: Chen, S.-C.; Lee, D.-S.; Huang, C.-Y. Evaluating the Sustainable Operating Performance of Electronics Industry Groups: Taiwanese Firms in Mainland China. Sustainability 2021, 13, 12030. https:// doi.org/10.3390/su132112030

Academic Editor: Franklin G. Mixon

Received: 30 September 2021

Accepted: 28 October 2021

Published: 31 October 2021

Publisher's Note: MDPI stays neutral with regard to jurisdictional claims in published maps and institutional affiliations.

Copyright: (c) 2021 by the authors. Licensee MDPI, Basel, Switzerland. This article is an open access article distributed under the terms and conditions of the Creative Commons Attribution (CC BY) license (https:/ / creativecommons.org/licenses/by/ $4.0 /)$.

\begin{abstract}
Mainland China's economy is growing rapidly, with China-made electronic products selling around the world. Taiwan's electronics groups running operations or production locations in Mainland China have performed strongly in recent years. At one time more than $90 \%$ of the world's laptops were manufactured by Taiwanese makers, largely in China. This study assessed the sustainability operating performance of the top 20 Taiwanese electronic groups (including 272 companies) with an average of 38 years of sustained operation in China, using the Data Envelopment Analysis Method (DEA) to measure the performance and operating efficiency of the group as a whole, with net operating revenue and pre-tax profit margin as the output elements, and total assets, capital, and total expenses as input elements, to assess whether changes in operating performance and productivity over the three-year period (2018-2020) are significant. The results showed that two Taiwanese electronics groups (Quanta Computer and Catcher Technology) were relatively efficient during the study period and that the overall productivity of the electronics groups was in a state of sustainability. This study uses the industrial cluster viewpoint to evaluate the sustainability operating performance of the groups. Results show that using DEA for performance evaluation is both comprehensive and practical. The findings of this study may be used as a reference in creating sustainable operations and improving a firm's production efficiency through the evaluation of firm resource allocation.
\end{abstract}

Keywords: DEA; efficiency; Taiwanese firms in mainland China; electronics industry groups; cluster competitiveness; sustainable operating performance

\section{Introduction}

In today's fierce global competitive environment, increasing the efficiency of the electronics industry is a priority. For investors, understanding the performance of a firm is important in making better investment decisions, while for managers, ensuring performance is the key to the sustainable long-term development of the company.

In the last forty years, there has been a significant increase in the number of electronic products, revolutionizing daily life in the areas of communication, entertainment, and personal productivity [1]. Taiwanese firms have played a leading role in these changes. For example, in Taiwan's LED (Light-Emitting Diode) industry, LiteOn Technology was established in 1975 and listed on the Taiwan Stock Market in 1983, Taiwan's first listed electronics firm. In the 1980s, Taiwan's electronics companies quietly blossomed, creating the Taiwanese LED industry miracle. After nearly 30 years, Taiwan's LED output ranked first in the world in 2000 [2]. During the 1985-1987 cyclical downturn in the semiconductor industry, the Taiwan Semiconductor Manufacturing Corporation (TSMC) established a joint venture with Phillips [3-5]. TSMC eventually became the world's leading firm in logic chip production after the late 1990s [6].

In the 1990s, to stay competitive, Taiwan enterprises began to move westward to China. The move began with the processing trade, followed by manufacturing and ser- 
vices. Taiwanese firms in China carried on their production relying on cheaper and better production factors in China. Engaging in production abroad is a widely adopted strategy of MNEs from advanced countries. It helps expand foreign market share and slows the decline in a firm's competitiveness under the wave of production fragmentation [7].

Since China's reform and opening-up in 1978, its economic growth has been significant, with GDP (Gross Domestic Product) per capita jumping 182.84 times from RMB 384.7 to RMB 70,724.6 in 2019. Since that time, China's e-product manufacturing sector has entirely reoriented itself from an industry-driven primarily by domestic markets, to a fundamentally export-driven sector. It is now the world's most important supplier of many, if not most, major e-products on the market today [8]. In the last decade, its importance as both a supplier and consumer of electronic goods has grown at an unprecedented pace [9]. Thus, the development of Taiwan's electronics industry in China has attracted the attention of researchers on the global economy. Central and Eastern European states have become heavily connected with China's production networks in the electronics industry. These linkages were noticed in particular in seven countries (Estonia, Hungary, Slovenia, the Czech Republic, Poland, Romania, and Slovenia), where foreign value-added embodied in their gross exports (FV) of electronics was significant [10].

Measurement of business performance enables managers and investors to (1) evaluate the company's past operating results; (2) use such results as a basis for predicting future enterprise development; (3) support management control, and (4) create a decision-making reference for the sustainable operation of the enterprise [11]. However, the efficiency of operations can determine the direction of operating efficiency and profit improvement. In the past, the primary application of DEA was to study a single company's operating efficiency. In this study, DEA is applied to analyze the operating efficiency of electronics industry conglomerates. This can accurately determine benchmark learning objectives for enterprise managers while enabling the enterprise to understand the group's sustainable competitiveness.

Just as China's electronics industry is getting faster, we need to get to know them from different aspects. This study collected a list of the top 20 electronic groups in mainland China with the continuous operating performance of the key subsidiaries and uses the DEA method to identify electronic groups with benchmarking effects, so that academics will help enrich the research of mainland China electronic enterprises in the past, also enable enterprise managers to strengthen the direction of continuous operation management in practical applications. This study will explain the research gap, contribution, and problem definition in Section 2.4.

To contribute further to the field of sustainable operation, this study surveys the operation from individual enterprise to the whole group and uses the DEA method which is objective and suitable for industrial practice to observe the Taiwan electronic Business Group in mainland China. The results can serve as an important reference for the continuous operation and development of the industry. The purposes of this study are (1) exploring the development of China's electronics industry and Taiwanese business groups in China and (2) establishing a group-based continuous operation efficiency evaluation from the perspective of industrial clusters and using the DEA method to identify benchmarking learning objects for the electronics industry. The results of our research should support firms and industries in strengthening their sustainable competitiveness.

The manuscript is organized as follows Section 2. Literature Review (including research gap, contribution, and problem definition). The methodology is described in Section 3. Results and Discussion is given in Section 4. Section 5 presents the Conclusion and research suggestions.

\section{Literature Review}

\section{1. $D E A$}

DEA, a programming-based approach, is applied in assessing Decision-Making Units (DMUs) such as departments or firms. A commonly-used technique, it can locate an indus- 
try's best-practice frontier and identify the gap between that frontier and an organization's outcomes. DEA is thus an approach for comparing an entity to its peers. When using DEA, the following requirements should be satisfied [12]:

- The data should not contain measurement errors.

- Convexity: if DMUs manage given input and output sets, the input and output set combinations are operable.

- Strong disposability: if a certain network configuration has a specified set of inputs and outputs, the network is capable of using greater inputs for lower outputs.

DEA is widely applied. For example, using DEA, Charnes, Cooper, and Rhodes assessed the decision-makers' productivity and efficiency [13]. Wang and Nguyen [14] used DEA to evaluate the effectiveness of investments of a group from 2013-2020. Chang, $\mathrm{Wu}$, Chang, and Lou adopted the DEA method to measure the technical efficiency of $85^{\circ} \mathrm{C}$, the benchmark enterprise of Taiwan's beverage industry [15]. The DEA method is widely used in the manufacturing industry [16] because DEA is the main measurement method of efficiency for DMUs. Moreover, DEA does not require any pre-hypotheses and can be used to measure the efficiency of DMUs with multiple inputs and multiple outputs, making it easier to use.

Several scholars have used DEA in performance evaluation. Lin, Yan, and Wang develop an inverse data envelopment analysis (IDEA) model for measuring container ports' efficiency and analyzing their resource consumption by considering undesirable outputs. Their results indicate that their proposed IDEA is a feasible approach for performance evaluation, and provides policymakers with insights into resource optimization of container ports [17]. Pachar, Darbari, Govindan, and Jha [18] develop a performance measurement model based on a two-stage network data envelopment analysis (DEA) technique for measuring the joint impact of sustainable operations and operational activities on the business performance of the Indian retail chain.

The DEA model has several advantages. First, it derives sole relative efficiency, which makes it suitable for use in a complex industrial environment. Second, the DEA approach does not require the imposition of a functional form on the underlying environmental technology. It also provides an easier and more flexible means of estimation [19]. Given this, the results of this study will help corporations in creating investment and business strategies. They may also be considered a foundation for management units, for local government in planning projects, for long-term planning vision, and for enhancing practical efficiency to quickly meet the needs of urban development plans.

The discussion of DEA models presented in this study is concise, further detailed reviews of the methodology can be referred to the papers presented by Seiford and Thrall [20], Lovell [21,22], Ali and Seiford [23], Charnes, Cooper, Lewin, and Seiford [24] and Seiford [25].

\subsubsection{CCR Model}

Charnes, Cooper, and Rhodes [13] published their classic performance evaluation model in 1978. The CCR model emphasizes the assumption of constant returns to scale under which for every additional investment, the resulting output increases. The CCR model posits that for $\mathrm{n}$ decision units of a similar nature, each decision unit has $\mathrm{m}$ inputs and s outputs. If the performance of the kth DMU is evaluated while considering the unit under evaluation, and maximizing the output relative to the constant input, the input-oriented efficiency assessment of the kth DMU may be obtained.

\subsubsection{BCC Model}

Banker, Charnes, and Cooper [26] developed a model for calculating efficiency values under variable returns to scale. Scholars note that there is not necessarily a clear mathematical relationship between inputs and maximum outputs, making it a chore to find specific production functions. The DEA efficiency assessment model projects all DMU inputs and outputs into geometry in search of the lowest or highest output as a boundary. When 
a DMU falls on a boundary, the DMU is considered efficient, and its relative efficiency value is one, which means that if conditions are unchanged, the DMU cannot reduce input or increase output. If the DMU falls within the boundary, the DMU is regarded as an inefficient unit, and an efficiency indicator between 0 and 1 is given. This means that when conditions remain the same, the input can be reduced and the output remains unchanged, or the output can be increased and the input remains unchanged.

When examining the issues of technical efficiency, scale efficiency, and return to scale, in the BCC model, the practice is to relax the Constant Return Scale (CRS) assumption of the CCR model to the Variable Return to Scale (VRS) model. Variable return to scale means that when the investment increases, the increase in output is not in a fixed proportion. Thus, the scale of production will affect its production efficiency. Therefore, the BCC model can evaluate technical efficiency and scale efficiency, especially for an inefficient DMU. The reason for its inefficiency may be the relationship between the scale and returns of the operation. By understanding the state of returns to scale of an individual DMU, it can provide managers with a more useful reference for improvement.

Generally speaking, the CRS model can evaluate Overall Efficiency (OE), while the VRS evaluates Technical Efficiency (TE). In other words, the constant returns to scale model is an efficiency evaluation in which all the evaluated units are compared together, while the variable returns to scale model compares the evaluated units under equivalent conditions. The difference between them is whether the production scale of the evaluated units is equivalent. However, it should be noted that in the assumption of the constant returns to scale model, whatever the scale of the assessed unit, it is subject to the same measurement standard, which is insufficient to accurately depict its differences. By the same token, variable returns to scale have special restrictions to make up for the lack of fixed returns to scale, and it remains impossible to evaluate a DMU for both technical efficiency and scale efficiency.

\subsection{Cluster Competitiveness}

Clusters are formed when the supply chain from upstream to downstream develops interactions and cooperation with economic benefits based on interdependency or geographic proximity. Companies in the cluster are competing against each other but are also dependent on each other. It is an ecosystem with mutual reliance, mutual benefits, and sharing. Geographic proximity also brings about many benefits, such as the sharing of industry information and geographic resources [27]. The resources and relationships associated with industry clusters have impacts on company performance and can enhance company competitiveness. Hsu, Laiy, and Lin (2013) constructed a list of five key factors of the strategic resources of clusters: (1) human resources; (2) knowledge resources; (3) technological infrastructure; (4) capital resources, and (5) firm infrastructure, which form the dimensions of their study [28]. Hence, whether a country has international competitiveness may depend on whether its advantageous industries can form industry clusters [29].

In 2019, the World Economic Forum (WEF) released its Global Competitiveness Report on the globe's economies. Taiwan ranked 12th among 141 economies. In the competitiveness of its industrial clusters (state of cluster development), it ranked third. The rankings of the industrial cluster competitiveness of Taiwan's economy and selected competitors in recent years are given in Table 1 [30].

\subsection{Taiwanese Firms in China and the Chinese Economy}

China's economy has been reforming and opening up since 1978 when it had a population of 960 million. By 2019 China's population had passed 1.4 billion, maintaining its status as the world's most populous economy. GDP per capita also increased from RMB 384.7 to RMB 70,724.6, an increase of 182.84 times in 1978. 
Table 1. Comparison of the competitiveness of Taiwan's industrial clusters.

\begin{tabular}{ccccc}
\hline \multirow{2}{*}{ Year Rank } & \multicolumn{4}{c}{ Economy } \\
\cline { 2 - 5 } & Singapore & United States & Italy & Taiwan \\
\hline 2019 Rank & 1st & 2nd & 30th & 12th \\
\hline $\begin{array}{c}\text { State of cluster development } \\
\text { Rank/141 }\end{array}$ & 10th & 2nd & 1st & 3rd \\
Remark & $\begin{array}{c}\text { State of cluster development Rank/Taiwan, China } \\
\text { 2018: 5th, 2017: 2nd, 2016: 3rd, 2015: 5th, 2014: 2nd, 2013: } \\
\text { 1st, 2012: 1st, 2011: 1st }\end{array}$ \\
\hline
\end{tabular}

China-United States trade war began in 2018. Given the economic performance of the United States and China in 2014 and 2019, the difference in GDP growth between the United States and China was already very small (2014 USA GDP 175,273 billion US\$, 2019 USA GDP 104,756 billion US\$, 2014 China GDP 104,756 billion US\$, 2019 China GDP 142,800 billion US\$), and China's GDP per capita growth rate from 2014 to $2019(32.53 \%)$ is also higher than that of the United States (17.88\%) [31].

According to a 2020 survey report on the top 1000 Taiwanese firms in China issued by the Commercial Times (investigation unit: China Credit Information Service, LTD, a CRIF company) [32], the total revenues of the top 1000 Taiwanese firms in 2020 was RMB 4790.7 billion, accounting for $4.83 \%$ of China's GDP. Over the previous decade, the highest proportion of GDP accounted for by Taiwanese firms in China was 7.69\% in 2012. In 2020, the total employment of the top 1000 Taiwanese companies in China was 3.26 million, while the highest total employment over the last decade was 3.44 million in 2017.

\subsection{Research Gap, Contribution, and Problem Definition}

Based on the literature review above, many studies have applied various DEA methods to measure the efficiency of each enterprise. However, there is very little relevant research focused on the continued operational efficiency of the groups, which is the gap in this study. This study uses the DEA approach to measure the continuous operation of the group, to enrich continuous operational efficiency related research of the Group's enterprise and industrial clusters.

The contributions of this study can be concluded as to follows:

(1) To summarize the economic development and review the development process of the electronics industry in China.

(2) From an industrial cluster perspective, sort out the top 20 mainland China electronics groups in revenue, which consisted of 272 companies with an annual revenue of over RMB 110 million.

(3) The implementation of the DEA performance measurement methodology is extended from the enterprise to the group. This study employs the DEA approach to measure the sustainable performance of a group, and to identify the benchmark group of the electronics industry.

The industrial competitiveness driven by industrial clusters/groups will increase the overall competitiveness of the economy. The problem definition of this study: How to find the benchmarking groups with relatively efficient continuous operation under objective premises. Is the electronic Taiwanese business group with the highest annual operating revenue or profitability as the benchmarking unit often used in the industry? The following sections will describe the DEA method used in this study and the related performance of the sustainable operations of the 20 major Taiwanese electronics groups (a sample from the top 1000 Taiwanese companies in mainland China). 


\section{Methodology}

DEA is a widely accepted approach for performance evaluation, since it does not require the user to impose any functional form on the performance index evaluations [33] and reflects the resource utilization of key inputs quantitatively [34,35]. Efficiency scores account for the multiple inputs consumed and multiple outputs produced by each DMU, without the need to specify their relative weights a priori [36]. Emrouznejad and Yang studied a number of DEA-related articles (including keywords), ranging from 1978 to the end of 2016, including theories and methods applied in a variety of scenarios [37]. Their study found that the keyword "industry cluster" was not in the 50 most commonly used keywords. The research discussed above generally focuses on the evaluation of a single enterprise. From the point of view of the industrial cluster, it is better to compare enterprises based on their industries. To make the weight more objective, this study used the DEA method to measure the operating efficiency of the electronics industry group.

\subsection{Efficiency Assessment Analysis Method}

DEA is a linear programming model that evaluates the relative efficiency of each DMU. It does not preset the relationship between input and output or weight and obtains the optimal efficiency value directly from the observed data of each unit. In the process of constructing the production function, since all data are enveloped under the production function by an envelopment, the envelopment is the theoretical basis of the DEA efficiency evaluation model. In the economic sense, this refers to the leading edge formed by the most favorable input and output, that is, "based on input data to determine the maximum output [38,39]." These efficiency units are connected by straight lines and curves to form an efficiency frontier. The use of the DEA for efficiency evaluation is primarily to measure the relationship between enterprises' inputs and their output. The results may be used as a standard of assessment, and may also help managers understand whether the internal resource allocation of the organization has been fully and effectively used $[40,41]$.

\subsection{Measurement and Selection of Input and Output Factors}

Electronics firms often face extremely short product life cycles with constantly and rapidly changing product and process technologies $[42,43]$. The average annual decline in prices for purchased parts has been approximately $10 \%$ per year, and the steepness of this curve is unique to the electronics industry [44].

The sample population of this study consists of Taiwanese business conglomerates operating in China. For representativeness and completeness, the data are drawn from the 2018-2020 Top 1000 Taiwanese firms' data published by the Taiwan Business Times. Considering the homogeneity of electronics conglomerates as the basis and considering the continuous competitiveness of regional industrial clusters, each electronics group is defined as a decision-making unit (DMU). A total of 20 DMUs are selected, the 20 largest electronics groups are composed of 272 group subsidiaries, and the Top 20 as shown in Table 2, which gives summary information on these firms.

The data from the China Credit Information Service company survey of the Top 1000 Taiwanese Businessmen in China are obtained by: (1) Questionnaire; (2) Secondary data (listed company announcement); and (3) Credit information database and other credit investigation methods (investigating companies with annual revenue exceeding RMB 110 million). The qualifications of Taiwanese enterprises in China are rigorous and consist of two categories. The company must be (1) a company legally established in China with a Taiwanese investor holding more than $45 \%$ of the shares, or (2) Taiwanese businessmen who diversify their equity or have special circumstances due to Taiwanese businessmen's overseas listing when Taiwanese businessmen are the actual operators of the firm even when their shareholding does not reach $45 \%$. 
Table 2. The brief of Top 20 Electronics Conglomerates.

\begin{tabular}{|c|c|c|c|c|}
\hline Group Name & $\begin{array}{c}\text { Year } \\
\text { Established }\end{array}$ & $\begin{array}{c}2019 \text { Group } \\
\text { Revenue Ranking }\end{array}$ & $\begin{array}{c}\text { Number of } \\
\text { Subsidiaries in Top } \\
1000 \text { Companies }\end{array}$ & $\begin{array}{l}\text { Main Products } \\
\text { (Product or Sale) }\end{array}$ \\
\hline Foxconn & 1974 & 1 & 81 & $\begin{array}{l}\text { Mobile Phone, Base Station, and } \\
\text { Manufacturing Electronic Products }\end{array}$ \\
\hline Kinpo Group & 1973 & 2 & 17 & Notebooks, PDA, and Cellphone \\
\hline Pegatron Corporation & 2007 & 3 & 16 & Electronic product manufacturing \\
\hline BenQ-AUO Group & 1984 & 4 & 19 & LCD \\
\hline Quanta Computer & 1988 & 5 & 9 & Motherboard and Microcomputer \\
\hline Wistron Corporation & 2001 & 6 & 14 & $\begin{array}{l}\text { Computer and peripheral } \\
\text { equipment \& supporting products }\end{array}$ \\
\hline Innolux Corporation & 2003 & 7 & 5 & $\begin{array}{l}\text { New Flat Panel Display Device, } \\
\text { New Electronic Components }\end{array}$ \\
\hline Inventec Corporation & 1975 & 8 & 7 & $\begin{array}{l}\text { Computer Product Assembly } \\
\text { and Sales }\end{array}$ \\
\hline $\begin{array}{l}\text { Walsin Lihwa } \\
\text { Corporation }\end{array}$ & 1966 & 9 & 19 & $\begin{array}{l}\text { TFT-LCD Flat panel display } \\
\text { (Thin Film Transistor -LCD) }\end{array}$ \\
\hline MiTAC Synnex Group & 1982 & 10 & 13 & $\begin{array}{l}\text { Distribution and maintenance of } \\
\text { IT Product }\end{array}$ \\
\hline ASE Technology & 1984 & 11 & 10 & Semiconductor Packaging Service \\
\hline Delta Electronics & 1971 & 12 & 13 & Power Supplier, Transformer \\
\hline LITE-ON Technology & 1975 & 13 & 18 & Power Supplier, Transformer \\
\hline AmTRAN Technology & 1994 & 14 & 2 & LCD, ION Display \\
\hline TPV Technology & 1990 & 15 & 4 & Production of LCD \\
\hline MSI Technology & 1986 & 16 & 3 & Motherboard \\
\hline Catcher Technology & 1994 & 17 & 5 & 3C product chassis and Mechanism \\
\hline Chimei Corporation & 1960 & 18 & 3 & Optoelectronic Components \\
\hline ASUSTeK Computer & 1989 & 19 & 4 & Sales Notebooks \\
\hline Clevo Chicony Group & 1983 & 20 & 10 & Keyboard \\
\hline
\end{tabular}

The 20 Groups: Average Duration in China: 38.05 years; The youngest Group is "Innolux": 15 years; The oldest Group is "Chimei Corporation": 62 years; Total Companies in the 20 Groups: 272.

Because of the short life cycle of electronic products discussed previously, the operational responsiveness of the electronics industry cannot be judged for a long period. If we use too long an operating cycle for evaluation, it will not reflect the real situation. This study uses the period 2018 to 2020 as its research period. DEAP 2.1 software (the outputoriented model and VRS are chosen) is used to analyze the overall technical efficiency (TE), pure technical efficiency (PTE), and scale efficiency (SE) of the 20 Taiwanese electronics conglomerates in China, and then extended to discuss the Slack Variable Analysis and Malmquist productivity index analysis.

Sustainable competitive advantage is also dependent on the ability of the firm to reintegrate its asset stocks and use them for new market opportunities [45]. Since the mid1980s, a change began to occur in the role played by employees within an organization [46]. This change meant that people were no longer considered an expense and began to be considered the main resource of a company [47], and business costs were then related to labor turnover, absenteeism, spoiled and defective goods, and reduced productivity [48]. When firms acquire knowledge from internal sources, this leads to increased innovation and sustainable performance [49]. Increasing labor productivity and employee eco-innovation 
Both the input and output of DEA must meet the conditions of high and positive correlation and meet the requirements of isotonicity. If there is a negative correlation between the two, the item should be removed. If the relationship of a certain element to each input and output element is weak, it is necessary to re-examine whether the element is an input or output element. In this study, the Pearson correlation coefficient is used to preliminarily verify the correlation between input factors and output factors. The correlation coefficients between the input and output items in this study are all positive values, passing the isotonicity diagnosis.

The results of Table 4 show that the correlation coefficients of the input factors and output factors in this study are all positive and both show a high degree of correlation. Therefore, it is inferred that the input factors and output factors selected are reasonable. All are selected as input factors and output factors.

Table 4. Correlation factors between input elements and output factors.

\begin{tabular}{|c|c|c|c|c|c|c|}
\hline & $\begin{array}{c}\text { Net } \\
\text { Revenue }\end{array}$ & $\begin{array}{l}\text { Net Profit } \\
\text { Before Tax }\end{array}$ & Total Assets & Capital & Net Value & Employee \\
\hline Net Revenue & 1 & & & & & \\
\hline $\begin{array}{l}\text { Net Profit } \\
\text { Before Tax }\end{array}$ & 0.817 & 1 & & & & \\
\hline Total assets & 0.968 & 0.838 & 1 & & & \\
\hline Capital & 0.933 & 0.823 & 0.977 & 1 & & \\
\hline Net value & 0.938 & 0.823 & 0.989 & 0.986 & 1 & \\
\hline Employee & 0.795 & 0.652 & 0.751 & 0.720 & 0.729 & 1 \\
\hline
\end{tabular}

\section{Results and Discussion}

\subsection{DEA Efficiency Analysis}

As the input and output data of the data envelopment analysis mode (1) must be non-negative, when the input and output data of some DMU (decision-making units) are negative, and the number of such DMU is small, the negative value is often replaced with a very small positive number (such as $10^{-6}$ ) to make it meet the requirements of the model (1). In the three years of 2018, 2019, and 2020, the net profit before tax of TPV Technology (DMU15) is negative each year. In addition, since the net profit before tax of ASUSTeK Computer (DMU19) in 2020 is also negative, the negative value is replaced by $10^{-6}$. The following Tables 5-7 present the results of the DEA analysis of the production efficiency value of 20 electronic Taiwan businessman groups in 2018, 2019, and 2020, respectively.

In 2018-2020, the annual returns to scale of each DMU is relatively efficient or is in (1) Increasing Returns to Scale, IRS, or (2) Decreasing Returns to Scale, DRS. As shown in Table 8, when an electronics group is in IRS, the production scale can be expanded to improve the scale efficiency. If an electronics group is in DRS, the production scale can be reduced to improve the scale efficiency.

From 2018 to 2020, the number of times each DMU was referenced by relatively inefficient Groups during the DEA analysis process is summarized and shown in Table 9. Among these firms, Pegatron Corporation, Walsin Lihwa Corporation, and Delta Electronics were referenced three times in 2018. In 2019, Kinpo Group, BenQ-AUO Group, Quanta Computer, Delta Electronics, TPV Technology, and Clevo Chicony Group were referenced twice. In 2020, Kinpo Group and BenQ-AUO Group were referenced three times. The more frequently a firm is referenced, the more they are regarded as benchmarks by their peers. Kinpo Group, BenQ-AUO Group, and Delta Electronics are the priority objects for reference. 
Table 5. 2018 DEA Productivity Value Analysis Statistics Table.

\begin{tabular}{|c|c|c|c|}
\hline \multirow[b]{2}{*}{ Group Name } & \multicolumn{3}{|c|}{2018} \\
\hline & $\begin{array}{c}\text { Technical Efficiency } \\
\text { (Crste) }\end{array}$ & $\begin{array}{c}\text { Technical Efficiency } \\
\text { (Vrste) }\end{array}$ & $\begin{array}{l}\text { Scale Efficiency } \\
\text { (Scale) }\end{array}$ \\
\hline Foxconn & 1.000 & 1.000 & 1.000 \\
\hline Kinpo Group & 1.000 & 1.000 & 1.000 \\
\hline Pegatron Corporation & 1.000 & 1.000 & 1.000 \\
\hline BenQ-AUO Group & 1.000 & 1.000 & 1.000 \\
\hline Quanta Computer & 1.000 & 1.000 & 1.000 \\
\hline Wistron Corporation & 1.000 & 1.000 & 1.000 \\
\hline Innolux Corporation & 1.000 & 1.000 & 1.000 \\
\hline Inventec Corporation & 1.000 & 1.000 & 1.000 \\
\hline $\begin{array}{l}\text { Walsin Lihwa } \\
\text { Corporation }\end{array}$ & 1.000 & 1.000 & 1.000 \\
\hline MiTAC Synnex Group & 0.403 & 0.507 & 0.794 \\
\hline ASE Technology & 0.331 & 0.374 & 0.884 \\
\hline Delta Electronics & 1.000 & 1.000 & 1.000 \\
\hline LITE-ON Technology & 0.813 & 0.986 & 0.824 \\
\hline AmTRAN Technology & 1.000 & 1.000 & 1.000 \\
\hline TPV Technology & 1.000 & 1.000 & 1.000 \\
\hline MSI Technology & 1.000 & 1.000 & 1.000 \\
\hline Catcher Technology & 1.000 & 1.000 & 1.000 \\
\hline Chimei Corporation & 0.262 & 0.266 & 0.983 \\
\hline ASUSTeK Computer & 0.793 & 1.000 & 0.793 \\
\hline Clevo Chicony Group & 1.000 & 1.000 & 1.000 \\
\hline Mean & 0.880 & 0.907 & 0.964 \\
\hline
\end{tabular}

Note: crste = technical efficiency from CRS DEA; vrste = technical efficiency from VRS DEA; scale = scale efficiency $=$ crste/vrste.

This study conducts a sensitivity analysis for the change decision-making unit and deletes the DMU with the highest number of references, and performs a comprehensive sensitivity analysis on other units to understand the changes in efficiency values nd reference sets. The final analysis shows the results after changing the decision-making unit when there is no excessive fluctuation in the overall efficiency performance. The relevant instructions are shown in Appendices A and B.

\subsection{Difference Variable Analysis (Slack Variable Analysis)}

The purpose of the Slack Variable Analysis is to analyze relatively inefficient DMUs, discuss their excessive input and insufficient output, and propose specific directions and ranges for improvement in the use of resources. This analysis can be used as a reference for improving performance.

Table 10 below is the Slack Variable Analysis table, in which DMU scores are given for each of the four indicators. A high number indicates that the unit under evaluation is underperforming in this project and is farther from the efficiency frontier. In the Total Assets variable, label 1 is Walsin Lihwa Corporation, which has the largest over-input of total assets. In the Capital variable, label 2 is the BenQ-AUO Group, which hosts the least efficient way for capital inputs to be converted into outputs. In the Net Value variable, label 3 indicates that Innolux Corporation has the largest difference in net value, which also shows that the return on equity may be low, and in the Number of Workers variable, label 
4 indicates that Catcher Technology has the highest slack in the number of workers in use, which means that the efficiency of the company's number of workers may be improved. If improvements are made to this project in the future, the smaller and closer to the envelope curve each group is, the more obvious the effect of the resource input will be.

\subsection{Malmquist Productivity Index Analysis}

The Malmquist Productivity Index is an extended model of DEA. It decomposes Total Factor Productivity Change (tfpch) into the technical efficiency change index (Technical Efficiency Change; effch) and the technological change index (Technological Change; techch). The total factor productivity change index (tfpch) measures the overall production efficiency change of the DMU. If the technological change index (tfpch) is greater than 1, the overall production efficiency is improving; otherwise, it means that the overall production efficiency is declining. An efficiency change (effch) greater than 1 means that the production efficiency is improving; otherwise, it means that the overall production efficiency is declining. The technology change index (techch) measures the level of the DMU's production technology. If the technology change index (techch) is greater than 1, it means that the DMU is exhibiting technological progress; otherwise, it signals technological decline.

Table 6. 2019 DEA Productivity Value Analysis Statistics Table.

\begin{tabular}{|c|c|c|c|}
\hline \multirow[b]{2}{*}{ Group Name } & \multicolumn{3}{|c|}{2019} \\
\hline & $\begin{array}{c}\text { Technical Efficiency } \\
\text { (Crste) }\end{array}$ & $\begin{array}{c}\text { Technical Efficiency } \\
\text { (Vrste) }\end{array}$ & $\begin{array}{l}\text { Scale Efficiency } \\
\text { (Scale) }\end{array}$ \\
\hline Foxconn & 1.000 & 1.000 & 1.000 \\
\hline Kinpo Group & 1.000 & 1.000 & 1.000 \\
\hline Pegatron Corporation & 1.000 & 1.000 & 1.000 \\
\hline BenQ-AUO Group & 1.000 & 1.000 & 1.000 \\
\hline Quanta Computer & 1.000 & 1.000 & 1.000 \\
\hline Wistron Corporation & 0.886 & 0.932 & 0.950 \\
\hline Innolux Corporation & 0.988 & 1.000 & 0.988 \\
\hline Inventec Corporation & 0.817 & 0.859 & 0.951 \\
\hline $\begin{array}{l}\text { Walsin Lihwa } \\
\text { Corporation }\end{array}$ & 0.641 & 1.000 & 0.641 \\
\hline MiTAC Synnex Group & 1.000 & 1.000 & 1.000 \\
\hline ASE Technology & 0.851 & 0.957 & 0.890 \\
\hline Delta Electronics & 1.000 & 1.000 & 1.000 \\
\hline LITE-ON Technology & 0.432 & 0.455 & 0.949 \\
\hline AmTRAN Technology & 1.000 & 1.000 & 1.000 \\
\hline TPV Technology & 1.000 & 1.000 & 1.000 \\
\hline MSI Technology & 0.879 & 1.000 & 0.879 \\
\hline Catcher Technology & 1.000 & 1.000 & 1.000 \\
\hline Chimei Corporation & 0.818 & 1.000 & 0.818 \\
\hline ASUSTeK Computer & 1.000 & 1.000 & 1.000 \\
\hline Clevo Chicony Group & 1.000 & 1.000 & 1.000 \\
\hline Mean & 0.916 & 0.960 & 0.953 \\
\hline
\end{tabular}


Table 7. 2020 DEA Productivity Value Analysis Statistics Table.

\begin{tabular}{|c|c|c|c|}
\hline \multirow[b]{2}{*}{ Group Name } & \multicolumn{3}{|c|}{2020} \\
\hline & $\begin{array}{c}\text { Technical Efficiency } \\
\text { (Crste) }\end{array}$ & $\begin{array}{c}\text { Technical Efficiency } \\
\text { (Vrste) }\end{array}$ & $\begin{array}{c}\text { Scale Efficiency } \\
\text { (Scale) }\end{array}$ \\
\hline Foxconn & 0.594 & 1.000 & 0.594 \\
\hline Kinpo Group & 1.000 & 1.000 & 1.000 \\
\hline Pegatron Corporation & 0.835 & 1.000 & 1.000 \\
\hline BenQ-AUO Group & 1.000 & 1.000 & 1.000 \\
\hline Quanta Computer & 1.000 & 1.000 & 1.000 \\
\hline Wistron Corporation & 1.000 & 1.000 & 1.000 \\
\hline Innolux Corporation & 0.613 & 0.996 & 0.615 \\
\hline Inventec Corporation & 0.969 & 0.978 & 0.991 \\
\hline $\begin{array}{l}\text { Walsin Lihwa } \\
\text { Corporation }\end{array}$ & 0.772 & 1.000 & 0.772 \\
\hline MiTAC Synnex Group & 1.000 & 1.000 & 1.000 \\
\hline ASE Technology & 0.105 & 0.106 & 0.992 \\
\hline Delta Electronics & 0.630 & 0.637 & 0.990 \\
\hline LITE-ON Technology & 1.000 & 1.000 & 1.000 \\
\hline AmTRAN Technology & 1.000 & 1.000 & 1.000 \\
\hline TPV Technology & 1.000 & 1.000 & 1.000 \\
\hline MSI Technology & 1.000 & 1.000 & 1.000 \\
\hline Catcher Technology & 1.000 & 1.000 & 1.000 \\
\hline Chimei Corporation & 0.538 & 0.808 & 0.666 \\
\hline ASUSTeK Computer & 1.000 & 1.000 & 1.000 \\
\hline Clevo Chicony Group & 0.684 & 1.000 & 0.684 \\
\hline Mean & 0.837 & 0.926 & 0.907 \\
\hline
\end{tabular}

Among these, the Technical Efficiency Change index (Technical Efficiency Change; effch), under the Variable Returns to Scale (VRS) can be divided into the Pure Technical Efficiency Change Index (Pure Technical Efficiency Change; pech) and the Scale Efficiency Change Index (Scale Efficiency Change; sech). Under the Variable Returns to Scale Model (VRS), if the Pure Technology Efficiency Change Index (pech) is greater than 1 it indicates progress in pure technology efficiency; otherwise, it shows a decline. The scale efficiency change index (sech) is used to measure whether the DMU reaches constant returns to scale (CRS). If the scale efficiency change index (sech) is greater than 1 , it means that period $t+1$ is closer to constant returns to scale (CRS) in production for period $t$, while the opposite means that it deviates from constant returns to scale in production.

1. Technical efficiency change index analysis (effch)

The Technical Efficiency Change Index Analysis (effch) refers to how the total technical efficiency (TE) of each DMU changes over the years.

2. Technology Change Analysis (techch)

Technical change analysis (techch) refers to technical improvements in different periods.

3. Analysis of changes in total factor productivity (tfpch) 
Table 8. 2018-2020 Return to Scale.

\begin{tabular}{|c|c|c|c|}
\hline \multirow{2}{*}{ Group Name } & \multicolumn{3}{|c|}{ Returns to Scale } \\
\hline & 2018 & 2019 & 2020 \\
\hline Foxconn & - & - & IRS \\
\hline Kinpo Group & - & - & - \\
\hline Pegatron Corporation & - & - & DRS \\
\hline BenQ-AUO Group & - & - & - \\
\hline Quanta Computer & - & - & - \\
\hline Wistron Corporation & - & DRS & - \\
\hline Innolux Corporation & - & IRS & DRS \\
\hline Inventec Corporation & - & IRS & DRS \\
\hline Walsin Lihwa Corporation & - & DRS & IRS \\
\hline MiTAC Synnex Group & IRS & - & - \\
\hline ASE Technology & DRS & DRS & IRS \\
\hline Delta Electronics & - & - & DRS \\
\hline LITE-ON Technology & DRS & DRS & - \\
\hline AmTRAN Technology & - & - & - \\
\hline TPV Technology & - & - & - \\
\hline MSI Technology & - & IRS & - \\
\hline Catcher Technology & - & - & - \\
\hline Chimei Corporation & IRS & IRS & DRS \\
\hline ASUSTeK Computer & IRS & - & - \\
\hline Clevo Chicony Group & - & - & DRS \\
\hline
\end{tabular}

Table 11 below presents the analysis of the Malmquist Productivity Index of the 20 Electronics Groups from 2018 to 2020.

4. Cross-period comparison of efficiency changes

Inter-period comparison of efficiency changes from 2018 to 2020 is present in Table 12.

Table 9. DMU reference frequency, 2018-2020.

\begin{tabular}{cccc}
\hline \multirow{2}{*}{ Group Name } & \multicolumn{2}{c}{ Returns to Scale } \\
\cline { 2 - 4 } & $\mathbf{2 0 1 8}$ & $\mathbf{2 0 1 9}$ & $\mathbf{2 0 2 0}$ \\
\hline Foxconn & 0 & 0 & 0 \\
\hline Kinpo Group & 1 & 2 & 3 \\
\hline Pegatron Corporation & 3 & 1 & 0 \\
\hline BenQ-AUO Group & 0 & 2 & 3 \\
\hline Quanta Computer & 0 & 2 & 1 \\
\hline Wistron Corporation & 1 & 0 & 1 \\
\hline Innolux Corporation & 0 & 0 & 0 \\
\hline Inventec Corporation & 2 & 0 & 0 \\
\hline
\end{tabular}


Table 9. Cont.

\begin{tabular}{cccc}
\hline \multirow{2}{*}{ Group Name } & \multicolumn{2}{c}{ Returns to Scale } \\
\cline { 2 - 4 } & $\mathbf{2 0 1 8}$ & $\mathbf{2 0 1 9}$ & $\mathbf{2 0 2 0}$ \\
\hline Walsin Lihwa Corporation & 3 & 0 & 1 \\
\hline MiTAC Synnex Group & 0 & 0 & 0 \\
\hline ASE Technology & 0 & 0 & 0 \\
\hline Delta Electronics & 3 & 2 & 0 \\
\hline LITE-ON Technology & 0 & 0 & 1 \\
\hline AmTRAN Technology & 0 & 1 & 0 \\
\hline TPV Technology & 2 & 2 & 0 \\
\hline MSI Technology & 0 & 0 & 1 \\
\hline Catcher Technology & 0 & 0 & 0 \\
\hline Chimei Corporation & 0 & 0 & 2 \\
\hline ASUSTeK Computer & 0 & 1 & 2 \\
\hline Clevo Chicony Group & 0 & 2 & \\
\hline
\end{tabular}

Table 10. Analysis of the slack variables for each input variable.

\begin{tabular}{ccccc}
\hline $\begin{array}{c}\text { Input } \\
\text { Group Name }\end{array}$ & Total Assets & Capital & Net Value & Employee \\
\hline Foxconn & 154.0 & 598.0 & 31.0 & 485.0 \\
\hline Kinpo Group & 867.0 & 4.0 & 836.0 & 346.0 \\
\hline Pegatron Corporation & 506.0 & 2.0 & 548.0 & 372.0 \\
\hline BenQ-AUO Group & 745.0 & 838.0 & 949.0 & 63.0 \\
\hline Quanta Computer & 240.0 & 502.0 & 187.0 & 123.0 \\
\hline Wistron Corporation & 790.0 & 2.0 & 428.6 & 304.4 \\
\hline Innolux Corporation & 300.0 & 2.0 & 969.0 & 354.0 \\
\hline Inventec Corporation & 594.6 & 614.5 & 678.0 & 64.0 \\
\hline Walsin Lihwa Corporation & 898.0 & 3.0 & 458.0 & 699.0 \\
\hline MiTAC Synnex Group & 212.0 & 733.0 & 460.0 & 20.0 \\
\hline ASE Technology & 267.0 & 3.0 & 116.0 & 327.1 \\
\hline Delta Electronics & 267.0 & 2.0 & 43.0 & 49.0 \\
\hline LITE-ON Technology & 523.5 & 425.0 & 683.2 & 23.0 \\
\hline AmTRAN Technology & 429.0 & 258.0 & 578.0 & 7.0 \\
\hline TPV Technology & 795.0 & 0.0 & 20.0 & 228.0 \\
\hline MSI Technology & 699.0 & 180.0 & 916.0 & 7.0 \\
\hline Catcher Technology & 15.0 & 6.0 & 82.0 & 970.0 \\
\hline Chimei Corporation & 170.0 & 1.0 & 342.0 & 110.0 \\
\hline ASUSTeK Computer & 801.0 & 430.0 & 561.0 & 116.0 \\
\hline Clevo Chicony Group & 98.0 & 1.0 & & \\
\hline & & & 116.0 \\
\hline
\end{tabular}


Table 11. Analysis of Malmquist Productivity Index of 20 Electronics Groups from 2018 to 2020.

\begin{tabular}{|c|c|c|c|c|c|}
\hline $\begin{array}{c}\text { Item } \\
\text { Group Name }\end{array}$ & $\begin{array}{c}\text { Technical } \\
\text { Efficiency Change } \\
\text { Index (effch) }\end{array}$ & $\begin{array}{l}\text { Technology } \\
\text { Change Index } \\
\text { (techch) }\end{array}$ & $\begin{array}{c}\text { Pure Technical } \\
\text { Efficiency Change Index } \\
\text { (pech) }\end{array}$ & $\begin{array}{l}\text { Scale Efficiency } \\
\text { Change Index } \\
\text { (sech) }\end{array}$ & $\begin{array}{l}\text { Changes in Total } \\
\text { Factor Productivity } \\
\text { (tfpch) }\end{array}$ \\
\hline Foxconn & 0.771 & 1.526 & 1.000 & 0.771 & 1.177 \\
\hline Kinpo Group & 1.000 & 0.992 & 1.000 & 1.000 & 0.992 \\
\hline Pegatron Corporation & 0.914 & 0.999 & 1.000 & 0.914 & 0.913 \\
\hline BenQ-AUO Group & 1.000 & 1.143 & 1.000 & 1.000 & 1.143 \\
\hline Quanta Computer & 1.000 & 1.092 & 1.000 & 1.000 & 1.092 \\
\hline Wistron Corporation & 1.000 & 1.135 & 1.000 & 1.000 & 1.135 \\
\hline Innolux Corporation & 0.783 & 1.306 & 0.998 & 0.784 & 1.023 \\
\hline Inventec Corporation & 0.984 & 0.948 & 0.989 & 0.995 & 0.933 \\
\hline Walsin Lihwa Corporation & 0.879 & 1.106 & 1.000 & 0.879 & 0.972 \\
\hline MiTAC Synnex Group & 1.576 & 0.814 & 1.375 & 1.146 & 1.284 \\
\hline ASE Technology & 0.563 & 1.190 & 0.532 & 1.059 & 0.670 \\
\hline Delta Electronics & 0.812 & 1.100 & 1.000 & 0.812 & 0.893 \\
\hline LITE-ON Technology & 1.109 & 1.244 & 1.007 & 1.101 & 1.380 \\
\hline AmTRAN Technology & 1.000 & 0.783 & 1.000 & 1.000 & 0.783 \\
\hline TPV Technology & 1.000 & 1.182 & 1.000 & 1.000 & 1.182 \\
\hline MSI Technology & 1.000 & 1.313 & 1.000 & 1.000 & 1.313 \\
\hline Catcher Technology & 1.000 & 1.294 & 1.000 & 1.000 & 1.294 \\
\hline Chimei Corporation & 1.766 & 1.240 & 1.711 & 1.032 & 2.190 \\
\hline ASUSTeK Computer & 1.123 & 1.538 & 1.000 & 1.123 & 1.727 \\
\hline Clevo Chicony Group & 1.000 & 0.948 & 1.000 & 1.000 & 0.948 \\
\hline Mean & 0.986 & 1.128 & 1.011 & 0.975 & 1.112 \\
\hline
\end{tabular}

Table 12. Inter-period comparison of efficiency changes from 2018 to 2020.

\begin{tabular}{cccccc}
\hline $\begin{array}{c}\text { Item } \\
\text { Year }\end{array}$ & $\begin{array}{c}\text { Technical } \\
\text { Efficiency Change } \\
\text { Index (effch) }\end{array}$ & $\begin{array}{c}\text { Technology } \\
\text { Change Index } \\
\text { (techch) }\end{array}$ & $\begin{array}{c}\text { Pure technical Efficiency } \\
\text { Change Index } \\
\text { (pech) }\end{array}$ & $\begin{array}{c}\text { Scale Efficiency } \\
\text { Change Index } \\
\text { (sech) }\end{array}$ & $\begin{array}{c}\text { Changes in Total } \\
\text { Factor Productivity } \\
\text { (tfpch) }\end{array}$ \\
\hline $2018-2019$ & 1.088 & 1.045 & 1.102 & 0.987 & 1.137 \\
\hline $2019-2020$ & 0.857 & 1.238 & 0.910 & 0.942 & 1.061 \\
\hline Mean & 0.966 & 1.138 & 1.002 & 0.964 & 1.098 \\
\hline
\end{tabular}

\subsection{Discussion of the Operational Management Performance of the Top 20 Electronics Groups}

The problem definition of this study is, under the objective premise that continuous operation has relative efficiency, how to find out the benchmark learning object, is the industry commonly used annual operating income or profit of the largest e-commerce group is the benchmark enterprise? The DEA method used in this study objectively identified 20 groups that were relatively effective in the same industry, and after comparing the results of the study, the annual income or profitability of the group was not the best goal for benchmark learning.

Among the top 20 electronic Taiwanese business groups, ranking first is Foxconn Group for the total numerical value of input and output variables, but the per capita output, per capita profit, and pre-tax income margin of Foxconn Group are below average. Given the "Law of Large Numbers" from the traditional point of view, the operational efficiency of Foxconn is not optimal. The average pre-tax income margin rate of the top 20 electronics groups in the last three years is shown in Table 13 below. 
Table 13. Statistics of top 20 electronics groups on per capita output and pre-tax income margin rate for the last three years.

\begin{tabular}{|c|c|c|c|c|}
\hline $\begin{array}{c}\text { Item } \\
\text { Group Name }\end{array}$ & $\begin{array}{c}\text { per Capita } \\
\text { Output } \\
(\mathrm{RMB} / 1000)\end{array}$ & $\begin{array}{l}\text { Above- } \\
\text { Average } \\
\text { or Not }\end{array}$ & $\begin{array}{c}\text { The Average } \\
\text { Pre-Tax Income } \\
\text { Margin Rate (\%) }\end{array}$ & $\begin{array}{c}\text { Above- } \\
\text { Average } \\
\text { or Not }\end{array}$ \\
\hline Foxconn & 1290 & $\mathrm{~N}$ & $2.06 \%$ & $\mathrm{~N}$ \\
\hline Kinpo Group & 2757 & Y & $1.12 \%$ & $\mathrm{~N}$ \\
\hline Pegatron Corporation & 2486 & Y & $1.17 \%$ & $\mathrm{~N}$ \\
\hline BenQ-AUO Group & 3118 & $\mathrm{Y}$ & $0.47 \%$ & $\mathrm{~N}$ \\
\hline Quanta Computer & 2304 & Y & $0.30 \%$ & $\mathrm{~N}$ \\
\hline Wistron Corporation & 3280 & $\mathrm{Y}$ & $0.90 \%$ & $\mathrm{~N}$ \\
\hline Innolux Corporation & 2938 & Y & $1.64 \%$ & $\mathrm{~N}$ \\
\hline Inventec Corporation & 2181 & $\mathrm{~N}$ & $0.46 \%$ & $\mathrm{~N}$ \\
\hline $\begin{array}{l}\text { Walsin Lihwa } \\
\text { Corporation }\end{array}$ & 2760 & Y & $2.74 \%$ & $\mathrm{~N}$ \\
\hline MiTAC Synnex Group & 3462 & $\mathrm{Y}$ & $2.11 \%$ & $\mathrm{~N}$ \\
\hline ASE Technology & 1317 & $\mathrm{~N}$ & $6.39 \%$ & Y \\
\hline Delta Electronics & 813 & $\mathrm{~N}$ & $4.39 \%$ & Y \\
\hline LITE-ON Technology & 1078 & $\mathrm{~N}$ & $3.21 \%$ & $\mathrm{Y}$ \\
\hline AmTRAN Technology & 4033 & Y & $0.60 \%$ & $\mathrm{~N}$ \\
\hline TPV Technology & 1982 & $\mathrm{~N}$ & $0.00 \%$ & $\mathrm{~N}$ \\
\hline MSI Technology & 2542 & Y & $0.63 \%$ & $\mathrm{~N}$ \\
\hline Catcher Technology & 541 & $\mathrm{~N}$ & $21.45 \%$ & Y \\
\hline Chimei Corporation & 1995 & $\mathrm{~N}$ & $6.83 \%$ & Y \\
\hline ASUSTeK Computer & 3089 & Y & $0.92 \%$ & $\mathrm{~N}$ \\
\hline Clevo Chicony Group & 926 & $\mathrm{~N}$ & $4.14 \%$ & Y \\
\hline Mean & 2245.52 & - & $3.08 \%$ & - \\
\hline
\end{tabular}

In addition, as a result of DEA analysis, overall, the two electronics groups, Quanta Computer and Catcher Technology, grow every year. The description is as follows:

(1) Quanta Computer

Though the profit margin of Quanta Group over the last three years is lower than the average of all groups, the per capita output of Quanta Group is higher than the average for all groups. During the period, Quanta Group exhibits a performance among the top five electronic groups in terms of per capita output with an average capital of RMB 3,552,925,000 whereas the average capital is RMB 9,515,235,000 for the top 20 electronics groups. Thus, Quanta Group only used about one-third of the average capital as that of the other groups to achieve such revenue. This is the main reason why simple setting pf weights does not make it easy to assess the relatively high efficiency of Quanta Group among the top 20 electronic groups.

\section{(2) Catcher Technology}

Although the per capita output of the Catcher Technology in the last three years is lower than the average of all groups, its pre-tax profit margin is $21.45 \%$ in the last three years, nearly seven times higher than average for all groups, $3.08 \%$. Therefore, using only operational indicators such as revenue, total assets, or capital to judge whether Catcher Technology is in a sustainable growth state risks distortion. 
Based on the above analysis and discussion results, the DEA method implemented in this study may be applied to the assessment of the sustainability of operating performance, avoiding subjective bias in determining weightings. In addition, the horizontal time axis setting can be used to generate the growth of the group in a given year. This enables users to quickly and clearly grasp the use of tools to analyze and understand the sustainability of the operating performance of an industry group.

\section{Conclusions}

\subsection{Conclusions}

This study adopts the perspective of industrial clusters and selects Taiwan electronics industry groups from among the top 1000 Taiwanese businesses in China, subsequent stratification sums up the output and input items of the subsidiaries of the same group one by one, finally using the concept of aggregation and match and conform to the DEA evaluation method to measure the continuous operating performance of the electronics industry group.

This study takes 20 electronics conglomerates from Taiwanese firms in China as the research objects for performance evaluation. The DEA model is used to measure the overall industrial operating efficiency, relative competitive efficiency, and each firm's own internal resource operating status. However, because the DEA model can only be used for singleperiod efficiency, this study also uses the Malmquist Productivity Index to explore the inter-period efficiency changes and technological changes of each electronics group. The benchmark group has relatively prominent operational performance in Technical efficiency, Pure Technical, and Scale efficiency. The ratio of input and output in the same industry found in this study may serve as an important reference for other groups. This study offers three major conclusions.

\section{DEA pattern analysis results}

Since 2018, the number of efficient electronics conglomerates has been declining every year. In the three years of this study, the most only efficient electronics conglomerates are Quanta Computer and Catcher Technology. Taking 2020 as an example, Quanta Computer's per capita output value (net revenue/number of employees) is RMB 2,285,290, while Catcher Technology is RMB 474,330. Though the output variables (net revenue and pre-tax net profit) of the two are not the highest among the top 20 electronics conglomerates, the performance of these two groups is relatively efficient, which highlights the comprehensiveness of the DEA performance evaluation.

2. According to the analysis of optimal returns to scale, as of 2020, most of these electronics conglomerates show increasing returns to scale. Only Foxconn, Walsin Lihwa Corporation, and ASE Technology have declining returns to scale in China.

3. Through Malmquist productivity index analysis, the productivity of the overall industry from 2018 to 2020 is in a state of decline, mainly because of the decline of the technological change index. This indicates that Taiwanese electronics firms in China need new research and development production technology to reduce costs and promote the improvement of overall industrial productivity through the development of new products.

\subsection{Research Suggestions}

This study assessed the sustainability operating performance of the top 20 Taiwanese electronic groups (including 272 companies) with an average of 38 years of sustained operation in China. This study has a few limitations, though each limitation highlights an area for future research. First, our research object is limited to Taiwanese electronics firms in China. To achieve sustainable development, we should place more emphasis on the creation and promotion of environmentally sustainable products and green consumerism, a key path to sustainability [62]. However, this research focuses on the sustainable development of the focus electronics companies in the economic aspects of sustainable operations. Thus, 
a limitation of this study is that we did not discuss the energy consumption of the electronics company and the industry groups.

We suggest that future research explore different regions, such as the electronics industry in Europe or India. In addition, because of difficulties in obtaining information on non-public firms in China, we can only obtain relevant data on 272 companies from 20 electronic groups. We suggest that future research conduct empirical research on different industry classifications (small, medium, and large industries) and conduct a comparative study of industries with characteristics similar to those of the electronics industry. We also suggest using a two-stage DEA approach for the electronics industry's efficiency evaluation, the Bi-Level Programming DEA approach enables computation of efficiency of each sub-stage as well as the overall efficiency of the stores [63].

The DEA method can rapidly and objectively determine the operating efficiency of firms and groups of firms. DEA is very sensitive to the differences between input and output variables and data. This study uses the DEA method to evaluate electronics manufacturing groups of the same nature as well as the same size. This enables such firms to plan for the frontier of efficiency and its management implications.

This study expands the business performance evaluation from a single company level to the conglomerate level. However, many variables of conglomerate performance, such as research and development costs, and non-operating income and expenses, should be explored in future studies. In addition, this study focuses only on electronic groups operated by Taiwanese firms in China. It will be more generalizable if future researchers expand it to encompass electronics conglomerates in other regions.

Author Contributions: Conceptualization, S.-C.C. and C.-Y.H.; methodology, S.-C.C.; formal analysis, S.-C.C.; resources, C.-Y.H. and D.-S.L.; writing—original draft preparation, S.-C.C.; writing—review and editing, C.-Y.H. and S.-C.C.; supervision, C.-Y.H. and D.-S.L. All authors have read and agreed to the published version of the manuscript.

Funding: This research received no external funding.

Institutional Review Board Statement: Not applicable.

Informed Consent Statement: Not applicable.

Data Availability Statement: The data are not publicly available due to its use on future research activities.

Conflicts of Interest: The authors declare no conflict of interest.

\section{Appendix A}

The Sensitivity Analysis in Table A1 shows that the efficiency values of Pegatron Corporation, Walsin Lihwa Corporation, and Delta Electronics are referenced 1 to 3 times, leading of all units. Thus, after deleting the data of these three electronic groups, the total number of units becomes 17 , and the total number of inputs and outputs are 6, still consistent with the rule of thumb for the use proposed by Golany and Roll [64]: "the number of decision units shall be at least twice the sum of inputs and outputs". After reviewing, the efficiency values of the 17 decision units are re-evaluated with the original 4 inputs and 2 output items to observe the stability of the efficiency of each unit. After the decision-making units Pegatron Corporation, Walsin Lihwa Corporation, and Delta Electronics were deleted, we conducted a comprehensive sensitivity analysis of the other 17 units. The efficiency value and the changes in the reference set were analyzed after deleting the 3 units relative to the first place. There is no excessive fluctuation in overall efficiency performance. 
Table A1. 20 Groups' Sensitivity Analysis, 2018 data.

\begin{tabular}{|c|c|c|c|c|c|}
\hline \multirow[b]{2}{*}{ Group Name } & \multicolumn{2}{|c|}{ 2018-20 DMUs } & \multirow[b]{2}{*}{ Group Name } & \multicolumn{2}{|c|}{ 2018-17 DMUs } \\
\hline & $\begin{array}{c}\text { Scale } \\
\text { Efficiency }\end{array}$ & $\begin{array}{l}\text { Group Reference } \\
\text { Frequency }\end{array}$ & & $\begin{array}{c}\text { Scale } \\
\text { Efficiency }\end{array}$ & $\begin{array}{l}\text { Group Reference } \\
\text { Frequency }\end{array}$ \\
\hline Foxconn & 1.000 & 0 & Foxconn & 1.000 & 0 \\
\hline Kinpo Group & 1.000 & 1 & Kinpo Group & 1.000 & 1 \\
\hline Pegatron Corporation & 1.000 & 3 & Pegatron Corporation & None & None \\
\hline BenQ-AUO Group & 1.000 & 0 & BenQ-AUO Group & 1.000 & 1 \\
\hline Quanta Computer & 1.000 & 0 & Quanta Computer & 1.000 & 0 \\
\hline Wistron Corporation & 1.000 & 1 & Wistron Corporation & 1.000 & 0 \\
\hline Innolux Corporation & 1.000 & 0 & Innolux Corporation & 1.000 & 0 \\
\hline Inventec Corporation & 1.000 & 2 & Inventec Corporation & 1.000 & 0 \\
\hline $\begin{array}{l}\text { Walsin Lihwa } \\
\text { Corporation }\end{array}$ & 1.000 & 3 & $\begin{array}{l}\text { Walsin Lihwa } \\
\text { Corporation }\end{array}$ & None & None \\
\hline MiTAC Synnex Group & 0.794 & 0 & MiTAC Synnex Group & 0.517 & 0 \\
\hline ASE Technology & 0.884 & 0 & ASE Technology & 0.982 & 0 \\
\hline Delta Electronics & 1.000 & 3 & Delta Electronics & None & None \\
\hline LITE-ON Technology & 0.824 & 0 & LITE-ON Technology & 1.000 & 2 \\
\hline AmTRAN Technology & 1.000 & 0 & AmTRAN Technology & 1.000 & 0 \\
\hline TPV Technology & 1.000 & 2 & TPV Technology & 1.000 & 2 \\
\hline MSI Technology & 1.000 & 0 & MSI Technology & 1.000 & 1 \\
\hline Catcher Technology & 1.000 & 0 & Catcher Technology & 1.000 & 0 \\
\hline Chimei Corporation & 0.983 & 0 & Chimei Corporation & 0.917 & 0 \\
\hline ASUSTeK Computer & 0.793 & 0 & ASUSTeK Computer & 0.798 & 0 \\
\hline Clevo Chicony Group & 1.000 & 0 & Clevo Chicony Group & 1.000 & 0 \\
\hline Mean & 0.964 & - & Group Name & 0.954 & - \\
\hline
\end{tabular}

Table A2 analysis shows that Kinpo Group, BenQ-AUO Group, Quanta Computer, Delta Electronics, TPV Technology, Clevo Chicony Group efficiency values are referenced 1 to 2 times, tops among all units. Thus, we delete the data of these six electronic groups. The total number of units becomes 14, and the total number of inputs and outputs remain 6 , still consistent with Golany and Roll [64] as discussed above. After review, the original 4 inputs and 2 output items are re-evaluated to determine the efficiency values of the other 14 decision units to observe the stability of the efficiency of each unit. After deleting Kinpo Group, BenQ-AUO Group, Quanta Computer, Delta Electronics, TPV Technology, and Clevo Chicony Group, a comprehensive sensitivity analysis of the other 14 units, and their efficiency values show that there is no significant fluctuation in overall efficiency performance after the six leading units are removed.

As shown by Table A3 analysis, the Kinpo Group and BenQ-AUO Group efficiency value is 1 and has been referenced 3 times, tops among all units. We thus delete the data of the two electronic groups, leaving 18 unit. The total number of inputs and outputs are 6, which follows Golany and Roll [64] as discussed above. After review, the original 4 inputs and 2 output items were re-evaluated to identify the efficiency values of the other 18 decision units and observe the stability of the efficiency of each unit. This study did a comprehensive sensitivity analysis of the remaining 18 units after Kinpo Group and BenQAUO Group were removed. The efficiency value for the overall efficiency of performance did not fluctuate excessively after removing the two units. 
Table A2. 20 Groups' Sensitivity Analysis, 2019 data.

\begin{tabular}{|c|c|c|c|c|c|}
\hline \multirow[b]{2}{*}{ Group Name } & \multicolumn{2}{|c|}{ 2019-20 DMUs } & \multirow[b]{2}{*}{ Group Name } & \multicolumn{2}{|c|}{ 2019-14 DMUs } \\
\hline & $\begin{array}{c}\text { Scale } \\
\text { Efficiency }\end{array}$ & $\begin{array}{l}\text { Group Reference } \\
\text { Frequency }\end{array}$ & & $\begin{array}{c}\text { Scale } \\
\text { Efficiency }\end{array}$ & $\begin{array}{l}\text { Group Reference } \\
\text { Frequency }\end{array}$ \\
\hline Foxconn & 1.000 & 0 & Foxconn & 1.000 & 0 \\
\hline Kinpo Group & 1.000 & 2 & Kinpo Group & None & None \\
\hline Pegatron Corporation & 1.000 & 1 & Pegatron Corporation & 1.000 & 0 \\
\hline BenQ-AUO Group & 1.000 & 2 & BenQ-AUO Group & None & None \\
\hline Quanta Computer & 1.000 & 2 & Quanta Computer & None & None \\
\hline Wistron Corporation & 0.950 & 0 & Wistron Corporation & 1.000 & 0 \\
\hline Innolux Corporation & 0.988 & 0 & Innolux Corporation & 1.000 & 0 \\
\hline Inventec Corporation & 0.951 & 0 & Inventec Corporation & 1.000 & 1 \\
\hline $\begin{array}{l}\text { Walsin Lihwa } \\
\text { Corporation }\end{array}$ & 0.641 & 0 & $\begin{array}{l}\text { Walsin Lihwa } \\
\text { Corporation }\end{array}$ & 1.000 & 0 \\
\hline MiTAC Synnex Group & 1.000 & 0 & MiTAC Synnex Group & 1.000 & 0 \\
\hline ASE Technology & 0.890 & 0 & ASE Technology & 1.000 & 0 \\
\hline Delta Electronics & 1.000 & 2 & Delta Electronics & None & None \\
\hline LITE-ON Technology & 0.949 & 0 & LITE-ON Technology & 0.515 & 0 \\
\hline AmTRAN Technology & 1.000 & 1 & AmTRAN Technology & 1.000 & 1 \\
\hline TPV Technology & 1.000 & 2 & TPV Technology & None & None \\
\hline MSI Technology & 0.879 & 0 & MSI Technology & 0.981 & 0 \\
\hline Catcher Technology & 1.000 & 0 & Catcher Technology & 1.000 & 0 \\
\hline Chimei Corporation & 0.818 & 0 & Chimei Corporation & 1.000 & 0 \\
\hline ASUSTeK Computer & 1.000 & 1 & ASUSTeK Computer & 1.000 & 0 \\
\hline Clevo Chicony Group & 1.000 & 2 & Clevo Chicony Group & None & None \\
\hline Mean & 0.953 & - & Mean & 0.989 & - \\
\hline
\end{tabular}

Table A3. 20 Groups' Sensitivity Analysis, 2020 data.

\begin{tabular}{|c|c|c|c|c|c|}
\hline \multirow[b]{2}{*}{ Group Name } & \multicolumn{2}{|c|}{$2020-20$ DMUs } & \multirow[b]{2}{*}{ Group Name } & \multicolumn{2}{|c|}{ 2020-18 DMUs } \\
\hline & $\begin{array}{c}\text { Scale } \\
\text { Efficiency }\end{array}$ & $\begin{array}{l}\text { Group Reference } \\
\text { Frequency }\end{array}$ & & $\begin{array}{c}\text { Scale } \\
\text { Efficiency }\end{array}$ & $\begin{array}{l}\text { Group Reference } \\
\text { Frequency }\end{array}$ \\
\hline Foxconn & 0.594 & 0 & Foxconn & 0.594 & 0 \\
\hline Kinpo Group & 1.000 & 3 & Kinpo Group & None & None \\
\hline Pegatron Corporation & 1.000 & 0 & Pegatron Corporation & 1.000 & 1 \\
\hline BenQ-AUO Group & 1.000 & 3 & BenQ-AUO Group & None & None \\
\hline Quanta Computer & 1.000 & 1 & Quanta Computer & 1.000 & 1 \\
\hline Wistron Corporation & 1.000 & 1 & Wistron Corporation & 1.000 & 1 \\
\hline Innolux Corporation & 0.615 & 0 & Innolux Corporation & 1.000 & 0 \\
\hline Inventec Corporation & 0.991 & 0 & Inventec Corporation & 0.991 & 0 \\
\hline $\begin{array}{l}\text { Walsin Lihwa } \\
\text { Corporation }\end{array}$ & 0.772 & 1 & $\begin{array}{l}\text { Walsin Lihwa } \\
\text { Corporation }\end{array}$ & 1.000 & 1 \\
\hline MiTAC Synnex Group & 1.000 & 0 & MiTAC Synnex Group & 1.000 & 0 \\
\hline
\end{tabular}


Table A3. Cont.

\begin{tabular}{|c|c|c|c|c|c|}
\hline \multirow[b]{2}{*}{ Group Name } & \multicolumn{2}{|c|}{$2020-20$ DMUs } & \multirow[b]{2}{*}{ Group Name } & \multicolumn{2}{|c|}{ 2020-18 DMUs } \\
\hline & $\begin{array}{c}\text { Scale } \\
\text { Efficiency }\end{array}$ & $\begin{array}{c}\text { Group Reference } \\
\text { Frequency }\end{array}$ & & $\begin{array}{c}\text { Scale } \\
\text { Efficiency }\end{array}$ & $\begin{array}{l}\text { Group Reference } \\
\text { Frequency }\end{array}$ \\
\hline ASE Technology & 0.992 & 0 & ASE Technology & 0.983 & 0 \\
\hline Delta Electronics & 0.990 & 0 & Delta Electronics & 0.719 & 0 \\
\hline LITE-ON Technology & 1.000 & 0 & LITE-ON Technology & 1.000 & 1 \\
\hline AmTRAN Technology & 1.000 & 1 & AmTRAN Technology & 1.000 & 1 \\
\hline TPV Technology & 1.000 & 0 & TPV Technology & 1.000 & 0 \\
\hline MSI Technology & 1.000 & 0 & MSI Technology & 1.000 & 0 \\
\hline Catcher Technology & 1.000 & 1 & Catcher Technology & 1.000 & 0 \\
\hline Chimei Corporation & 0.666 & 0 & Chimei Corporation & 0.658 & 0 \\
\hline ASUSTeK Computer & 1.000 & 2 & ASUSTeK Computer & 1.000 & 1 \\
\hline Clevo Chicony Group & 0.684 & 2 & Clevo Chicony Group & 0.684 & 1 \\
\hline Mean & 0.907 & - & Group Name & 0.924 & - \\
\hline
\end{tabular}

\section{Appendix B}

Malmquist Productivity Index of Electronic Groups

1. Foxconn

Table A4 shows the Foxconn Group Malmquist Productivity Index, in which total factor productivity changes decreased by $17.45 \%$ from 1.295 to 1.069 , representing the Group's declining productivity, mainly due to the impact of the Technology Efficiency Change Index (effch), indicating a decline in the Group's production technology or waste of resources.

Table A4. Malmquist index of Foxconn Group.

\begin{tabular}{cccccc}
\hline $\begin{array}{c}\text { Item } \\
\text { Year }\end{array}$ & $\begin{array}{c}\text { Technical } \\
\text { Efficiency Change } \\
\text { Index (effch) }\end{array}$ & $\begin{array}{c}\text { Technology } \\
\text { Change Index } \\
\text { (techch) }\end{array}$ & $\begin{array}{c}\text { Pure Technical Efficiency } \\
\text { Change Index } \\
\text { (pech) }\end{array}$ & $\begin{array}{c}\text { Scale Efficiency } \\
\text { Change Index } \\
\text { (sech) }\end{array}$ & $\begin{array}{c}\text { Changes in Total } \\
\text { Factor Productivity } \\
\text { (tfpch) }\end{array}$ \\
\hline $2018-2019$ & 1.000 & 1.295 & 1.000 & 1.000 & 1.295 \\
\hline $2019-2020$ & 0.594 & 1.799 & 1.000 & 0.594 & 1.069 \\
\hline
\end{tabular}

2. Kinpo

Table A5 shows the Kinpo Group Malmquist Productivity Index, where total factor productivity changes increased by $34.19 \%$ from 0.860 to 1.154 , representing the Group's growth in productivity, mainly due to the impact of the Technology Change Index (techch), which shows that the Group innovation of production technologies and products is growing.

Table A5. Malmquist index of Kinpo Group.

\begin{tabular}{cccccc}
\hline $\begin{array}{l}\text { Item } \\
\text { Year }\end{array}$ & $\begin{array}{c}\text { Technical } \\
\text { Efficiency Change } \\
\text { index (effch) }\end{array}$ & $\begin{array}{c}\text { Technology } \\
\text { Change Index } \\
\text { (techch) }\end{array}$ & $\begin{array}{c}\text { Pure Technical Efficiency } \\
\text { Change Index } \\
\text { (pech) }\end{array}$ & $\begin{array}{c}\text { Scale Efficiency } \\
\text { Change Index } \\
\text { (sech) }\end{array}$ & $\begin{array}{c}\text { Changes in Total } \\
\text { Factor Productivity } \\
\text { (tfpch) }\end{array}$ \\
\hline $2018-2019$ & 1.000 & 0.860 & 1.000 & 1.000 & 0.860 \\
\hline $2019-2020$ & 1.000 & 1.154 & 1.000 & 1.000 & 1.154 \\
\hline
\end{tabular}




\section{Pegatron}

Table A6 shows the Pegatron Group Malmquist Productivity Index, with total factor productivity changes rising from 0.742 to 1.148 , an increase of $54.72 \%$.

Table A6. Malmquist index of Pegatron Group.

\begin{tabular}{cccccc}
\hline $\begin{array}{l}\text { Item } \\
\text { Year }\end{array}$ & $\begin{array}{c}\text { Technical } \\
\text { Efficiency Change } \\
\text { Index (effch) }\end{array}$ & $\begin{array}{c}\text { Technology } \\
\text { Change Index } \\
\text { (techch) }\end{array}$ & $\begin{array}{c}\text { Pure technical Efficiency } \\
\text { Change Index } \\
\text { (pech) }\end{array}$ & $\begin{array}{c}\text { Scale Efficiency } \\
\text { Change Index } \\
\text { (sech) }\end{array}$ & $\begin{array}{c}\text { Changes in Total } \\
\text { Factor Productivity } \\
\text { (tfpch) }\end{array}$ \\
\hline $2018-2019$ & 1.000 & 0.742 & 1.000 & 1.000 & 0.742 \\
\hline $2019-2020$ & 0.835 & 1.375 & 1.000 & 0.835 & 1.148 \\
\hline
\end{tabular}

\section{BenQ-AUO}

Table A7 shows the BenQ-AUO Group Malmquist Productivity Index, with total factor productivity changes rising from 0.993 to 1.465 , an increase of $47.53 \%$.

Table A7. Malmquist index of BenQ-AUO Group.

\begin{tabular}{cccccc}
\hline $\begin{array}{c}\text { Item } \\
\text { Year }\end{array}$ & $\begin{array}{c}\text { Technical } \\
\text { efficiency Change } \\
\text { index (effch) }\end{array}$ & $\begin{array}{c}\text { Technology } \\
\text { Change Index } \\
\text { (techch) }\end{array}$ & $\begin{array}{c}\text { Pure Technical Efficiency } \\
\text { Change Index } \\
\text { (pech) }\end{array}$ & $\begin{array}{c}\text { Scale Efficiency } \\
\text { Change Index } \\
\text { (sech) }\end{array}$ & $\begin{array}{c}\text { Changes in Total } \\
\text { Factor Productivity } \\
\text { (tfpch) }\end{array}$ \\
\hline $2018-2019$ & 1.000 & 0.993 & 1.000 & 1.000 & 0.993 \\
\hline $2019-2020$ & 1.000 & 1.465 & 1.000 & 1.000 & 1.465 \\
\hline
\end{tabular}

5. Quanta

Table A8 shows the Quanta Group Malmquist Productivity Index, in which total factor productivity changes decreased from 1.319 to 0.904 , a decline of $31.46 \%$.

Table A8. Malmquist index of BenQ-AUO Group.

\begin{tabular}{cccccc}
\hline $\begin{array}{l}\text { Item } \\
\text { Year }\end{array}$ & $\begin{array}{c}\text { Technical } \\
\text { Efficiency Change } \\
\text { Index (effch) }\end{array}$ & $\begin{array}{c}\text { Technology } \\
\text { Change Index } \\
\text { (techch) }\end{array}$ & $\begin{array}{c}\text { Pure Technical Efficiency } \\
\text { Change Index } \\
\text { (pech) }\end{array}$ & $\begin{array}{c}\text { Scale Efficiency } \\
\text { Change Index } \\
\text { (sech) }\end{array}$ & $\begin{array}{c}\text { Changes in Total } \\
\text { Factor Productivity } \\
\text { (tfpch) }\end{array}$ \\
\hline $2018-2019$ & 1.000 & 1.319 & 1.000 & 1.000 & 1.319 \\
\hline $2019-2020$ & 1.000 & 0.904 & 1.000 & 1.000 & 0.904 \\
\hline
\end{tabular}

6. Wistron

Table A9 shows the Wistron Group Malmquist Productivity Index, with total factor productivity changes rising from 0.740 to 1.764 , an increase of $138.38 \%$.

Table A9. Malmquist index of Wistron Group.

\begin{tabular}{cccccc}
\hline $\begin{array}{c}\text { Item } \\
\text { Year }\end{array}$ & $\begin{array}{c}\text { Technical } \\
\text { Efficiency Change } \\
\text { Index (effch) }\end{array}$ & $\begin{array}{c}\text { Technology } \\
\text { Change Index } \\
\text { (techch) }\end{array}$ & $\begin{array}{c}\text { Pure Technical Efficiency } \\
\text { Change Index } \\
\text { (pech) }\end{array}$ & $\begin{array}{c}\text { Scale Efficiency } \\
\text { Change Index } \\
\text { (sech) }\end{array}$ & $\begin{array}{c}\text { Changes in Total } \\
\text { Factor Productivity } \\
\text { (tfpch) }\end{array}$ \\
\hline $2018-2019$ & 0.886 & 0.836 & 0.932 & 0.950 & 0.740 \\
\hline $2019-2020$ & 1.129 & 1.563 & 1.073 & 1.053 & 1.764 \\
\hline
\end{tabular}

7. Innolux

Table A10 shows the Innolux Group Malmquist Productivity Index, with total factor productivity changes rising from 0.896 to 1.150 , an increase of $28.35 \%$. 
Table A10. Malmquist index of Innolux Group.

\begin{tabular}{cccccc}
\hline $\begin{array}{l}\text { Item } \\
\text { Year }\end{array}$ & $\begin{array}{c}\text { Technical } \\
\text { Efficiency Change } \\
\text { Index (effch) }\end{array}$ & $\begin{array}{c}\text { Technology } \\
\text { Change Index } \\
\text { (techch) }\end{array}$ & $\begin{array}{c}\text { Pure Technical Efficiency } \\
\text { Change Index } \\
\text { (pech) }\end{array}$ & $\begin{array}{c}\text { Scale Efficiency } \\
\text { Change Index } \\
\text { (sech) }\end{array}$ & $\begin{array}{c}\text { Changes in Total } \\
\text { Factor Productivity } \\
\text { (tfpch) }\end{array}$ \\
\hline $2018-2019$ & 0.988 & 0.907 & 1.000 & 0.988 & 0.896 \\
\hline $2019-2020$ & 0.620 & 1.854 & 0.996 & 0.623 & 1.150 \\
\hline
\end{tabular}

8. Inventec

Table A11 shows the Inventec Group Malmquist Productivity Index, with total factor productivity changes rising from 0.770 to 1.131 , an increase of $46.88 \%$.

Table A11. Malmquist index of Inventec Group.

\begin{tabular}{cccccc}
\hline $\begin{array}{c}\text { Item } \\
\text { Year }\end{array}$ & $\begin{array}{c}\text { Technical } \\
\text { Efficiency Change } \\
\text { Index (effch) }\end{array}$ & $\begin{array}{c}\text { Technology } \\
\text { Change Index } \\
\text { (techch) }\end{array}$ & $\begin{array}{c}\text { Pure Technical Efficiency } \\
\text { Change Index } \\
\text { (pech) }\end{array}$ & $\begin{array}{c}\text { Scale Efficiency } \\
\text { Change Index } \\
\text { (sech) }\end{array}$ & $\begin{array}{c}\text { Changes in Total } \\
\text { Factor Productivity } \\
\text { (tfpch) }\end{array}$ \\
\hline $2018-2019$ & 0.817 & 0.942 & 0.859 & 0.951 & 0.770 \\
\hline $2019-2020$ & 1.186 & 0.954 & 1.139 & 1.041 & 1.131 \\
\hline
\end{tabular}

9. Walsin Lihwa

Table A12 shows the Walsin Lihwa Group Malmquist Productivity Index, with total factor productivity changes rising from 0.564 to 1.853 , an increase of $228.55 \%$.

Table A12. Malmquist index of Walsin Lihwa Group.

\begin{tabular}{cccccc}
\hline $\begin{array}{c}\text { Item } \\
\text { Year }\end{array}$ & $\begin{array}{c}\text { Technical } \\
\text { Efficiency Change } \\
\text { Index (effch) }\end{array}$ & $\begin{array}{c}\text { Technology } \\
\text { Change Index } \\
\text { (techch) }\end{array}$ & $\begin{array}{c}\text { Pure Technical Efficiency } \\
\text { Change Index } \\
\text { (pech) }\end{array}$ & $\begin{array}{c}\text { Scale Efficiency } \\
\text { Change Index } \\
\text { (sech) }\end{array}$ & $\begin{array}{c}\text { Changes in Total } \\
\text { Factor Productivity } \\
\text { (tfpch) }\end{array}$ \\
\hline $2018-2019$ & 0.641 & 0.880 & 1.000 & 0.641 & 0.564 \\
\hline $2019-2020$ & 1.204 & 1.539 & 1.000 & 1.204 & 1.853 \\
\hline
\end{tabular}

10. MiTAC Synnex

Table A13 shows the Quanta Group Malmquist Productivity Index, in which total factor productivity changes decreased from 1.875 to 0.879 , a decrease of $53.12 \%$.

Table A13. Malmquist index of MiTAC Synnex Group.

\begin{tabular}{cccccc}
\hline $\begin{array}{l}\text { Item } \\
\text { Year }\end{array}$ & $\begin{array}{c}\text { Technical } \\
\text { Efficiency Change } \\
\text { Index (effch) }\end{array}$ & $\begin{array}{c}\text { Technology } \\
\text { Change Index } \\
\text { (techch) }\end{array}$ & $\begin{array}{c}\text { Pure Technical Efficiency } \\
\text { Change Index } \\
\text { (pech) }\end{array}$ & $\begin{array}{c}\text { Scale Efficiency } \\
\text { Change Index } \\
\text { (sech) }\end{array}$ & $\begin{array}{c}\text { Changes in Total } \\
\text { Factor Productivity } \\
\text { (tfpch) }\end{array}$ \\
\hline $2018-2019$ & 2.484 & 0.755 & 1.972 & 1.260 & 1.875 \\
\hline $2019-2020$ & 1.000 & 0.879 & 1.000 & 1.000 & 0.879 \\
\hline
\end{tabular}

11. ASE

Table A14 below shows the ASE Group Malmquist Productivity Index, where total factor productivity changes decreased from 2.541 to 0.162 , a decline of $93.62 \%$.

Table A14. Malmquist index of ASE Group.

\begin{tabular}{|c|c|c|c|c|c|}
\hline $\begin{array}{l}\text { Item } \\
\text { Year }\end{array}$ & $\begin{array}{c}\text { Technical Efficiency } \\
\text { Change Index } \\
\text { (effch) }\end{array}$ & $\begin{array}{l}\text { Technology } \\
\text { Change Index } \\
\text { (techch) }\end{array}$ & $\begin{array}{c}\text { Pure Technical Efficiency } \\
\text { Change Index } \\
\text { (pech) }\end{array}$ & $\begin{array}{l}\text { Scale Efficiency } \\
\text { Change Index } \\
\text { (sech) }\end{array}$ & $\begin{array}{c}\text { Changes in Total Factor } \\
\text { Productivity } \\
\text { (tfpch) }\end{array}$ \\
\hline 2018-2019 & 2.573 & 0.988 & 2.556 & 1.007 & 2.541 \\
\hline 2019-2020 & 0.123 & 1.316 & 0.111 & 1.115 & 0.162 \\
\hline
\end{tabular}




\section{Delta}

Table A15 shows the Delta Group Malmquist Productivity Index, in which total factor productivity changes decreased from 1.541 to 0.481 , a decline of $68.79 \%$.

Table A15. Malmquist index of Delta Group.

\begin{tabular}{cccccc}
\hline $\begin{array}{l}\text { Item } \\
\text { Year }\end{array}$ & $\begin{array}{c}\text { Technical } \\
\text { Efficiency Change } \\
\text { Index (effch) }\end{array}$ & $\begin{array}{c}\text { Technology } \\
\text { Change Index } \\
\text { (techch) }\end{array}$ & $\begin{array}{c}\text { Pure Technical Efficiency } \\
\text { Change Index } \\
\text { (pech) }\end{array}$ & $\begin{array}{c}\text { Scale Efficiency } \\
\text { Change Index } \\
\text { (sech) }\end{array}$ & $\begin{array}{c}\text { Changes in Total } \\
\text { Factor Productivity } \\
\text { (tfpch) }\end{array}$ \\
\hline $2018-2019$ & 1.000 & 1.541 & 1.000 & 1.000 & 1.541 \\
\hline $2019-2020$ & 0.630 & 0.763 & 0.637 & 0.990 & 0.481 \\
\hline
\end{tabular}

\section{LITE-ON}

Table A16 shows the LITE-ON Group Malmquist Productivity Index, with total factor productivity changes rising from 0.641 to 2.929 , an increase of $356.94 \%$.

Table A16. Malmquist index of LITE-ON Group.

\begin{tabular}{cccccc}
\hline $\begin{array}{c}\text { Item } \\
\text { Year }\end{array}$ & $\begin{array}{c}\text { Technical } \\
\text { Efficiency Change } \\
\text { Index (effch) }\end{array}$ & $\begin{array}{c}\text { Technology } \\
\text { Change Index } \\
\text { (techch) }\end{array}$ & $\begin{array}{c}\text { Pure Technical Efficiency } \\
\text { Change Index } \\
\text { (pech) }\end{array}$ & $\begin{array}{c}\text { Scale Efficiency } \\
\text { Change Index } \\
\text { (sech) }\end{array}$ & $\begin{array}{c}\text { Changes in Total } \\
\text { Factor Productivity } \\
\text { (tfpch) }\end{array}$ \\
\hline $2018-2019$ & 0.532 & 1.205 & 0.462 & 1.152 & 0.641 \\
\hline $2019-2020$ & 2.313 & 1.267 & 2.196 & 1.053 & 2.929 \\
\hline
\end{tabular}

\section{AmTRAN}

Table A17 shows the AmTRAN Group Malmquist Productivity Index, with total factor productivity changes falling from 0.809 to 0.758 , a decline of $6.3 \%$.

Table A17. Malmquist index of AmTRAN Group.

\begin{tabular}{cccccc}
\hline $\begin{array}{l}\text { Item } \\
\text { Year }\end{array}$ & $\begin{array}{c}\text { Technical } \\
\text { Efficiency Change } \\
\text { Index (effch) }\end{array}$ & $\begin{array}{c}\text { Technology } \\
\text { Change Index } \\
\text { (techch) }\end{array}$ & $\begin{array}{c}\text { Pure Technical Efficiency } \\
\text { Change Index } \\
\text { (pech) }\end{array}$ & $\begin{array}{c}\text { Scale Efficiency } \\
\text { Change Index } \\
\text { (sech) }\end{array}$ & $\begin{array}{c}\text { Changes in Total } \\
\text { Factor Productivity } \\
\text { (tfpch) }\end{array}$ \\
\hline $2018-2019$ & 1.000 & 0.809 & 1.000 & 1.000 & 0.809 \\
\hline $2019-2020$ & 1.000 & 0.758 & 1.000 & 1.000 & 0.758 \\
\hline
\end{tabular}

\section{TPV}

Table A18 shows the TPV Group Malmquist Productivity Index, in which total factor productivity changes decreased from 1.057 to 1.048 , a decrease of $0.85 \%$.

Table A18. Malmquist index of TPV Group.

\begin{tabular}{cccccc}
\hline $\begin{array}{l}\text { Item } \\
\text { Year }\end{array}$ & $\begin{array}{c}\text { Technical } \\
\text { Efficiency Change } \\
\text { Index (effch) }\end{array}$ & $\begin{array}{c}\text { Technology } \\
\text { Change Index } \\
\text { (techch) }\end{array}$ & $\begin{array}{c}\text { Pure Technical Efficiency } \\
\text { Change Index } \\
\text { (pech) }\end{array}$ & $\begin{array}{c}\text { Scale Efficiency } \\
\text { Change Index } \\
\text { (sech) }\end{array}$ & $\begin{array}{c}\text { Changes in Total } \\
\text { Factor Productivity } \\
\text { (tfpch) }\end{array}$ \\
\hline $2018-2019$ & 1.000 & 1.057 & 1.000 & 1.000 & 1.057 \\
\hline $2019-2020$ & 1.000 & 1.048 & 1.000 & 1.000 & 1.048 \\
\hline
\end{tabular}

16. MSI

Table A19 shows the MSI Group Malmquist Productivity Index, with total factor productivity changes rising from 0.899 to 1.917 , an increase of $113.24 \%$. 
Table A19. Malmquist index of MSI Group.

\begin{tabular}{cccccc}
\hline $\begin{array}{l}\text { Item } \\
\text { Year }\end{array}$ & $\begin{array}{c}\text { Technical } \\
\text { Efficiency Change } \\
\text { Index (effch) }\end{array}$ & $\begin{array}{c}\text { Technology } \\
\text { Change Index } \\
\text { (techch) }\end{array}$ & $\begin{array}{c}\text { Pure Technical Efficiency } \\
\text { Change Index } \\
\text { (pech) }\end{array}$ & $\begin{array}{c}\text { Scale Efficiency } \\
\text { Change Index } \\
\text { (sech) }\end{array}$ & $\begin{array}{c}\text { Changes in Total } \\
\text { Factor Productivity } \\
\text { (tfpch) }\end{array}$ \\
\hline $2018-2019$ & 0.879 & 1.022 & 1.000 & 0.879 & 0.899 \\
\hline $2019-2020$ & 1.137 & 1.685 & 1.000 & 1.137 & 1.917 \\
\hline
\end{tabular}

17. Catcher

Table A20 shows the Catcher Group Malmquist Productivity Index, where total factor productivity changes decreased from 1.424 to 1.177 , a decline of $17.35 \%$.

Table A20. Malmquist index of Catcher Group.

\begin{tabular}{cccccc}
\hline $\begin{array}{l}\text { Item } \\
\text { Year }\end{array}$ & $\begin{array}{c}\text { Technical } \\
\text { Efficiency Change } \\
\text { Index (effch) }\end{array}$ & $\begin{array}{c}\text { Technology } \\
\text { Change Index } \\
\text { (techch) }\end{array}$ & $\begin{array}{c}\text { Pure Technical Efficiency } \\
\text { Change Index } \\
\text { (pech) }\end{array}$ & $\begin{array}{c}\text { Scale Efficiency } \\
\text { Change Index } \\
\text { (sech) }\end{array}$ & $\begin{array}{c}\text { Changes in Total } \\
\text { Factor Productivity } \\
\text { (tfpch) }\end{array}$ \\
\hline $2018-2019$ & 1.000 & 1.424 & 1.000 & 1.000 & 1.424 \\
\hline $2019-2020$ & 1.000 & 1.177 & 1.000 & 1.000 & 1.177 \\
\hline
\end{tabular}

18. Chimei

Table A21 shows the Chimei Group Malmquist Productivity Index, where total factor productivity changes decreased from 3.565 to 1.214 , a decline of $65.95 \%$.

Table A21. Malmquist index of Chimei Group.

\begin{tabular}{cccccc}
\hline $\begin{array}{c}\text { Item. } \\
\text { Year }\end{array}$ & $\begin{array}{c}\text { Technical } \\
\text { Efficiency Change } \\
\text { Index (effch) }\end{array}$ & $\begin{array}{c}\text { Technology } \\
\text { Change Index } \\
\text { (techch) }\end{array}$ & $\begin{array}{c}\text { Pure Technical Efficiency } \\
\text { Change Index } \\
\text { (pech) }\end{array}$ & $\begin{array}{c}\text { Scale Efficiency } \\
\text { Change Index } \\
\text { (sech) }\end{array}$ & $\begin{array}{c}\text { Changes in Total } \\
\text { Factor Productivity } \\
\text { (tfpch) }\end{array}$ \\
\hline $2018-2019$ & 3.121 & 1.142 & 3.752 & 0.832 & 3.565 \\
\hline $2019-2020$ & 0.658 & 1.845 & 0.808 & 0.814 & 1.214 \\
\hline
\end{tabular}

19. ASUS

Table A22 shows the ASUS Group Malmquist Productivity Index, with total factor productivity changes rising from 1.714 to 1.831 , an increase of $6.83 \%$.

Table A22. Malmquist index of ASUS Group.

\begin{tabular}{cccccc}
\hline $\begin{array}{l}\text { Item } \\
\text { Year }\end{array}$ & $\begin{array}{c}\text { Technical } \\
\text { Efficiency Change } \\
\text { Index (effch) }\end{array}$ & $\begin{array}{c}\text { Technology } \\
\text { Change Index } \\
\text { (techch) }\end{array}$ & $\begin{array}{c}\text { Pure Technical Efficiency } \\
\text { Change Index } \\
\text { (pech) }\end{array}$ & $\begin{array}{c}\text { Scale Efficiency } \\
\text { Change Index } \\
\text { (sech) }\end{array}$ & $\begin{array}{c}\text { Changes in Total } \\
\text { Factor Productivity } \\
\text { (tfpch) }\end{array}$ \\
\hline $2018-2019$ & 1.261 & 1.360 & 1.000 & 1.261 & 1.714 \\
\hline $2019-2020$ & 1.000 & 1.831 & 1.000 & 1.000 & 1.831 \\
\hline
\end{tabular}

20. Clevo Chicony

Table A23 shows the Clevo Chicony Group Malmquist Productivity Index, where total factor productivity changes decreased from 1.331 to 0.512 , a decline of $61.53 \%$.

Table A23. Malmquist index of Clevo Chicony Group.

\begin{tabular}{|c|c|c|c|c|c|}
\hline $\begin{array}{l}\text { Item } \\
\text { Year }\end{array}$ & $\begin{array}{c}\text { Technical Efficiency } \\
\text { Change Index } \\
\text { (effch) }\end{array}$ & $\begin{array}{l}\text { Technology } \\
\text { Change Index } \\
\text { (techch) }\end{array}$ & $\begin{array}{l}\text { Pure Technical Efficiency } \\
\text { Change Index } \\
\text { (pech) }\end{array}$ & $\begin{array}{l}\text { Scale Efficiency } \\
\text { Change Index } \\
\text { (sech) }\end{array}$ & $\begin{array}{l}\text { Changes in Total Factor } \\
\text { Productivity (tfpch) }\end{array}$ \\
\hline 2018-2019 & 1.000 & 1.331 & 1.000 & 1.000 & 1.331 \\
\hline 2019-2020 & 0.684 & 0.748 & 1.000 & 0.684 & 0.512 \\
\hline
\end{tabular}




\section{References}

1. Goncalves da Costa, L.; Ferreira, J.; Kumar, V.; Garza-Reyes, J. Benchmarking of sustainability to assess practices and performances of the management of the end of life cycle of electronic products a study of Brazilian manufacturing companies. Clean Technol. Environ. Policy 2020. [CrossRef]

2. $\quad$ Lee, S.C.; Tsai, J.S. The LED Legacy: How Heroes Built LED Business in Taiwan; Commonwealth Publishing: Taipei, Taiwan, $2010 ;$ pp. 10-16.

3. Tsai, K.; Wang, J. An Examination of Taiwan's Innovation Policy Measures and their Effects. Int. J. Technol. Glob. 2005, 1, 239-257. [CrossRef]

4. Yap, X.S. From Zero to Hero: Latecomer Catch-Up Strategies in the Integrated Circuit Industry. Ph.D. Thesis, University of Malaya, Kuala Lumpur, Malaysia, 19 March 2013.

5. Rajah, R.; Yap, X.S.; Han, V.G.R. Crisis Effects on the Electronics Industry in Southeast Asia. J. Contemp. Asia 2014, 44, 645-663.

6. Mathews, J.; Cho, D. Tiger Technology: The Creation of a Semiconductor Industry in East Asia; Cambridge University Press: Cambridge, $\mathrm{UK}, 2000$.

7. Ho, C.C.; Lin, H.L.; Yang, C.H.; Lyu, Y.P. Productivity Catch-up between Chinese and Taiwanese Electronics Firms. Pac. Econ. Rev. 2017, 22, 533-553. [CrossRef]

8. Duan, H.; Eugster, M.; Hischier, R.; Streicher-Porte, M.; Li, J. Life cycle assessment study of a Chinese desktop personal computer. Sci. Total Environ. 2009, 407, 1755-1764. [CrossRef] [PubMed]

9. Wong, S.; El-Abd, H. Why electronics in China-A business perspective. IEEE Trans. Compon. Packag. Technol. 2003, 26, 276-280. [CrossRef]

10. Cieślik, E. Shifting from the EU's production networks Electronics industry exports of Central and Eastern Europe. Appl. Econ. Lett. 2020, 27, 52-57. [CrossRef]

11. Chen, T.Y.; Chen, C.B. Business Diagnosis and Performance Evaluation; Strategic Management Perspective, 5th ed.; Hwa Tai Publishing: Taipei, Taiwan, 2018.

12. Pourhejazy, P.; Kwon, O.K.; Chang, Y.T.; Park, H. Evaluating Resiliency of Supply Chain Network: A Data Envelopment Analysis Approach. Sustainability 2017, 9, 255. [CrossRef]

13. Charnes, A.; Cooper, W.W.; Rhodes, E. Measuring the Efficiency of Decision Making Units. Eur. J. Oper. Res. 1978, 2, 429-444. [CrossRef]

14. Wang, C.N.; Nguyen, H.K. Enhancing Urban Development Quality Based on the Results of Appraising Efficient Performance of Investors-A Case Study in Vietnam. Sustainability 2017, 9, 1397. [CrossRef]

15. Chang, C.W.; Wu, K.S.; Chang, B.G.; Lou, K.R. Measuring Technical Efficiency and Returns to Scale in Taiwan's Baking IndustryA Case Study of the $85^{\circ} \mathrm{C}$ Company. Sustainability 2019, 11, 1268. [CrossRef]

16. Huang, C.Y.; Tsai, M.F.; Huang, H.H. Performance Evaluation of six sigma Projects-An Data Envelopment Analysis approach J. Technol. 2009, 24, 117-130.

17. Lin, Y.; Yan, L.; Wang, Y.M. Performance Evaluation and Investment Analysis for Container Port Sustainable Development in China: An Inverse DEA Approach. Sustainability 2019, 11, 4617. [CrossRef]

18. Pachar, N.; Darbari, J.D.; Govindan, K.; Jha, P.C. Sustainable performance measurement of Indian retail chain using two-stage network DEA. Ann. Oper. Res. 2021. [CrossRef]

19. Zhang, N.; Kong, F.; Kung, C.C. On Modeling Environmental Production Characteristics: A Slacks-Based Measure for China's Poyang Lake Ecological Economics Zone. Comput. Econ. 2015, 46, 389-404. [CrossRef]

20. Seiford, L.M.; Thrall, R.M. Recent Developments in DEA: The Mathematical Approach to Frontier Analysis. J. Econom. 1990, 46, 7-38. [CrossRef]

21. Lovell, C.A.K. Production Frontiers and Productive Efficiency. In The Measurement of Productive Efficiency; Fried, H.O., Lovell, C.A.K., Schmidt, S.S., Eds.; Oxford University Press: New York, NY, USA, 1993; pp. 3-67.

22. Lovell, C.A.K. Linear Programming Approaches to the Measurement and Analysis of Productive Efficiency. Top 1994, 2, 175-248. [CrossRef]

23. Ali, A.I.; Seiford, L.M. The Mathematical Programming Approach to Efficiency Analysis. In The Measurement of Productive Efficiency; Fried, H.O., Lovell, C.A.K., Schmidt, S.S., Eds.; Oxford University Press: New York, NY, USA, 1993; pp. $120-159$.

24. Charnes, A.; Cooper, W.W.; Lewin, A.Y.; Seiford, L.M. Data Envelopment Analysis: Theory, Methodology and Applications, Kluwer. J. Oper. Res. Soc. 1995, 48, 332-333. [CrossRef]

25. Seiford, L.M. Data Envelopment Analysis: The Evolution of the State of the Art (1978-1995). J. Product. Anal. 1996, 7, 99-138. [CrossRef]

26. Banker, R.D.; Charnes, A.; Cooper, W.W. Some Models for Estimating Technical and Scale Inefficiencies in Data Envelopment Analysis. Manag. Sci. 1984, 30, 1078-1092. [CrossRef]

27. Porter, M.E. Clusters and the new economics of competition. Harv. Bus. Rev. 1998, 76, 77-90. [PubMed]

28. Hsu, M.S.; Laiy, Y.L.; Lin, F.J. Effects of Industry Clusters on Company Competitiveness: Special Economic Zones in Taiwan. Rev. Pac. Basin Financ. Mark. Policies 2013, 16, 1350017. [CrossRef]

29. Porter, M.E. The Competitive Advantage of Nations; Free Press: New York, NY, USA, 1990.

30. World Economic Forum (WEF). The Global Competitiveness Report; World Economic Forum: Geneva, Switzerland, 2019. 
31. Compiled by National Bureau of Statistics of China, China Statistical Yearbook. 2020. Available online: http://www.stats.gov.cn/ tjsj/ndsj/2020/indexch.htm (accessed on 4 May 2021).

32. Commercial Times. TOP 1000 Taiwanese Firms in China; Commercial Times: Taipei, Taiwan, 2020.

33. Choi, Y.; Zhang, N.; Zhou, P. Efficiency andabatement costs of energy-related $\mathrm{CO}_{2}$, emissions in China: A slacks-based efficiency measure. Appl. Energy 2012, 98, 198-208. [CrossRef]

34. Narayanan, S.; Swaminathan, J.M.; Talluri, S. Knowledge diversity, turnover, and organizational-unit productivity: An empirical analysis in a knowledge-intensive context. Prod. Oper. Manag. 2014, 23, 1332-1351. [CrossRef]

35. Yu, A.; Shi, Y.; You, J.; Zhu, J. Innovation performance evaluation for high-tech companies using a dynamic network data envelopment analysis approach. Eur. J. Oper. Res. 2021, 292, 199-212. [CrossRef]

36. Huang, T.Y.; Tai, T.L. The Evaluation of Efficiency in Taiwan's Steel Industry (2009 2011)—An Application of Data Envelopment Analysis. Bull. Natl. Pingtung Inst. Commer. 2013, 15, 373-420.

37. Emrouznejad, A.; Yang, G.L. A survey and analysis of the first 40 years of scholarly literature in DEA: 1978-2016. Socio-Econ. Plan. Sci. 2018, 61, 4-8. [CrossRef]

38. Charnes, A.; Cooper, W.W. Programming with linear fractional functionals. Nav. Res. Logist. Q. 1962, 9, 181-186. [CrossRef]

39. Coelli, T.J. A Guide to DEAP Version 2.1: A Data Envelopment Analysis Computer Program, Center for Efficiency and Productivity Analysis, Working Paper 96/08; University of New England: Amidale, Australia, 1996.

40. Guan, C.; Fan, Y. The Impact of Social Networks on the Operating Effciency of Chinese Technology Business Incubators. Sustainability 2020, 12, 2727. [CrossRef]

41. Song, K.H.; Choi, S.; Han, H. Competitiveness Evaluation Methodology for Aviation Industry Sustainability Using Network DEA. Sustainability 2020, 12, 10323. [CrossRef]

42. Fine, C.H. Clockspeed-based strategies for supply chain design. Prod. Oper. Manag. 2000, 9, 213-221. [CrossRef]

43. Mallick, D.N.; Schroeder, R.G. An integrated framework for measuring production development performance in high technology industries. Prod. Oper. Manag. 2005, 14, 142-158. [CrossRef]

44. Cimento, A.P.; Knister, R.J. The high-productivity electronics company. McKinsey Q. 1994, 1, 21-32.

45. Huang, Y.C.; Borazon, E.Q.; Liu, J.M. Antecedents and consequences of green supply chain management in Taiwan's electric and electronic industry. J. Manuf. Technol. Manag. 2021, 32, 1066-1093. [CrossRef]

46. Gil Flores, J. Assessment of Professional Competences. Educ. XX1 2007, 10, 83-106.

47. Obisi, C. Employee performance appraisal and its implication for individual and organizational growth. Aust. J. Bus. Manag. Res. 2011, 1, 92-97. [CrossRef]

48. Andersson, E.R. Economic evaluation of ergonomic solutions: Part 1-Guidelines for the Practitioner. Int. J. Ind. Ergon. 1992, 10, 161-171. [CrossRef]

49. Hájek, P.; Stejskal, J. R\&D Cooperation and Knowledge Spillover Effects for Sustainable Business Innovation in the Chemical Industry. Sustainability 2018, 10, 1064.

50. Bucea-Manea-T,oniş, R.; Prokop, V.; Ilic, D.; Gurgu, E.; Bucea-Manea-Țoniş, R.; Braicu, C.; Moanta, A. The Relationship between Eco-Innovation and Smart Working as Support for Sustainable Management. Sustainability 2021, 13, 1437. [CrossRef]

51. Xiong, H.; Zhou, Y. Construction and Application of Ocean Shipping Enterprise Performance Evaluation System Based on Environmental Value Chain. J. Coast. Res. 2019, 97, 29-34. [CrossRef]

52. Chou, Y.C.; Shao, B.B.M.; Lin, W.T. Performance evaluation of production of IT capital goods across OECD countries A stochastic frontier approach to Malmquist index. Decis. Support Syst. 2012, 54, 173-184. [CrossRef]

53. Brynjolfsson, E.; Hitt, L.M. Paradox lost? Firm-level evidence on the returns to information systems spending. Manag. Sci. 1996, 42, 541-558. [CrossRef]

54. Dewan, S.; Kraemer, K.L. Information technology and productivity: Evidence from country-level data. Manag. Sci. 2000, 46, 548-562. [CrossRef]

55. Lin, W.T.; Shao, B.B.M. Relative sizes of information technology investments and productive efficiency: Their linkage and empirical evidence. J. Assoc. Inf. Syst. 2000, 1, 1-35. [CrossRef]

56. Shao, B.B.M.; Lin, W.T. Technical efficiency analysis of information technology investments: A two-stage empirical investigation. Inf. Manag. 2002, 39, 391-401. [CrossRef]

57. Hitt, L.M.; Brynjolfsson, E. Productivity, business profitability, and consumer surplus: Three different measures of information technology value. MIS Q. 1996, 20, 121-142. [CrossRef]

58. Tam, K.Y. The impact of information technology investments on firm performance and evaluation: Evidence from newly industrialized economies. Inf. Syst. Res. 1998, 9, 85-98. [CrossRef]

59. Mitra, S.; Chaya, A.K. Analyzing cost-effectiveness of organizations: The impact of information technology spending. J. Manag. Inf. Syst. 1996, 13, 29-57. [CrossRef]

60. Jorgenson, D.W.; Ho, M.S.; Stiroh, K.J. A retrospective look at the U.S. productivity growth resurgence. J. Econ. Perspect. 2008, 22, 3-24. [CrossRef]

61. Oliner, S.D.; Sichel, D.E. Information technology and productivity: Where are we now and where are we going? J. Policy Modeling 2003, 25, 477-503. [CrossRef] 
62. Hojnik, J.; Ruzzier, M.; Ruzzier, M.K. Transition towards Sustainability: Adoption of Eco-Products among Consumers. Sustainability 2019, 11, 4308. [CrossRef]

63. Pachar, N.; Gupta, A.; Jha, P.C. Bi-Level Programming DEA Approach for Efficiency Evaluation: A Case Study of Indian Electronics Retails Stores. Yugosl. J. Oper. Res. 2020, 30, 461-481. [CrossRef]

64. Golany, B.; Roll, Y. An Application Procedure for DEA. OMEGA 1989, 17, 237-250. [CrossRef] 